\title{
ON THE REGENERATION AND FINER STRUCTURE OF THE ARMS OF THE CEPHALOPODS
}

\author{
MATHILDE M. LANGE
}

THIRTY-NINE ILLUSTRATIONS

\section{CONTENTS}

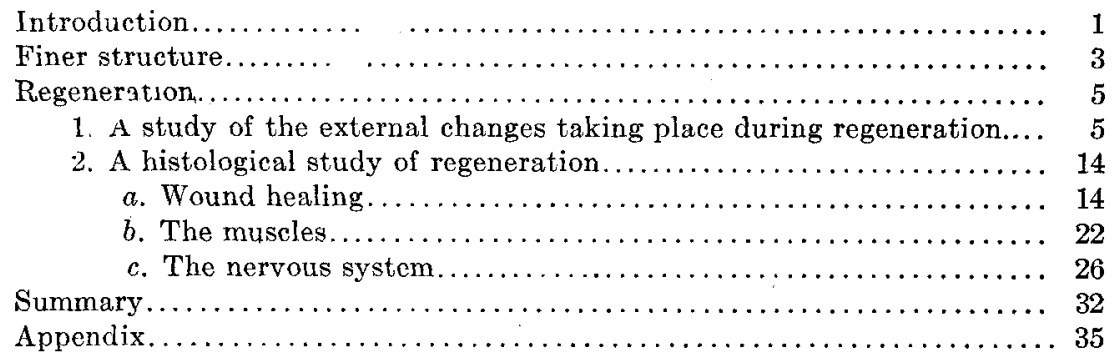

\section{INTRODUCTION}

The ability of the cephalopods to renew lost parts of their arms is a fact which has been revealed to us through the discovery of several specimens whose injured tentacles were in the process of regeneration. Verrill ('82) found such cephalopods off the northeastern coast of North America and Brock ('86) reported the presence of similar ones in the Indian Ocean. Eisig and Riggenbach ('01) observed the formation of a regeneration bud on the tentacle of Octopus de Filipi after autotomy, and Hanko ('13) published a paper describing an octopus tentacle which at the upper end had been split into two parts, each part retaining the function of a normal arm. But all these reports lack a detailed description of the process of regeneration, no experimental investigation of this subjeet having been published up to the present. At the suggestion of Prof. C. Chun, I decided to make a closer study of this phenomenon. I feel indebted to the late Professor Chun for this suggestion. Unfortunately, he died just as I began my investigations. His assistant, Doctor Grimpe, kindly assisted me during the early stages of my work. 
I wish to thank him for the interest he took in its progress. I also wish to express my thanks to Professor Hescheler, in whose laboratory I finished this study, and to Dr. Marie Daiber. Their valuable suggestions were of great help to me.

The specimens necessary for the work were gathered at the Zoological Station of Naples and at the Musée Océanographie at Monaco. Octopus vulgaris, Eledone moschata, and Sepia officinalis were the three species chiefly employed. At first I encountered some difficulty in keeping the animals. My experience taught me that non-transparent aquaria were better suited to the purpose than plain glass basins and that the water must flow into the basin slowly, as a strong current is harmful to the well-being of the animals. If the basin is large enough, it is advisable to turn the water off for a couple of hours every day. The food consisted mainly of live crabs. In case the basin is inhabited by more than one animal, it is best not simply to throw in the food, but to feed each animal singly, in order to prevent fighting, as the animals often injure their arms in this way, and such injuries are liable to retard regeneration. Animals whose lens was extirpated were narcotized in a solution which consisted of four parts of 25 per cent alcoholic chloreton, and 96 parts water (sea-water). The animal remained in this solution from three to five minutes. In order to hasten revival after operation, air was pumped into the mantel-cavity and pressed out again. This proved quite a stimulant to respiration. The narcotic poison which is secreted by the gills generally gathers in the funnel. It is advisable to rid the animal of this poison by inserting a probe into the funnel.

The specimens were fixed in the following solutions: Flemming's strong mixture, Hermann's solution, a mixture of formalin, alcohol and acetic acid, and also in a mixture of mercuric chloride, alcohol and acetic acid. Several pieces were fixed in 10 per cent formalin and several in neutral formalin. If enough animals are available, it is advisable to fix an entire animal for each successive stage, but if the scarcity of animals necessitates the use of one and the same animal to produce several stages, it is imperative that regenerated ends be eut off under water. Special 
attention must be paid to this, as otherwise air penetrates the tissues. The presence of air in the tissues renders their impregnation with paraffin or other media extremely difficult, and thus the microtome work very unsatisfactory. Combinations of celloidin and paraffin and also of collodium and paraffin proved the most practical substances for embedding. The pieces after being well drained in alcohol (100 per cent) were placed in a mixture of equal parts of alcohol and ether, and remained there for several hours. They were then put into a diluted solution of celloidin or collodium for 24 hours. The pieces impregnated with collodium were then left in oil of origanum for 24 hours, and the celloidin pieces were submitted to the same treatment in cedar oil. Later they were immersed in a mixture of oil of origanum plus $40^{\circ}$ paraffin, and cedar oil plus $40^{\circ}$ paraffin, respectively, and remained in these mixtures for twenty-four hours. Thereupon they were placed in several baths of paraffin of different degrees, and finally in $58^{\circ}$ paraffin, in which they were embedded. The 100 per cent alcohol had hardened the tissues to such a degree that microtoming was exceedingly difficult. It was therefore necessary to employ mastic-collodium. No albuminous glycerin, only distillated water was used for mounting. The slides were further treated in the usual way. Photoxolin was not used; on the contrary, the mastic-collodium was removed by a solution of equal parts of alcohol and ether. The sections were stained on the slide with haemalaun (Mayer) haematoxylin (Heidenhain), eosin, orange $G$ several of the specimens fixed in osmic, were stained saffranin plus emerald green. The best stains were obtained by a combination of haematoxylin (Heidenhain) plus eosin. Some specimens were stained by way of impregnation, according to the method of Bielschowsky and Maresch.

\section{THE FINER STRUCTURE OF THE ARM}

The anatomy of the arm of the cephalopods has often been made the object of closer study. Cuvier's publication 1817 gives quite a minute description of it. Since then a number of authors have devoted their attention to the same subject. Colo- 
santi ('76) was the first to make the tentacle of the octopus the subject of a microscopical examination. The best paper published on this subject up to the present was written by Guérin ('08).

The arm of the cephalopod consists of four distinct parts: first, the skin or integument; second, the muscles; third, the nervous system, and, fourth, the vascular system.

The skin is composed of two layers, the epidermis and the dermis. The epidermis consists of a single sheet and is covered by striated cuticle. The nuclei of its cells are quite large and contain granules. The unicellular glands are more or less pearshaped in comparison with the ordinary epithelial cells, their plasm contains fewer granules and they are much smaller. The dermis of the octopus arm consists of connective tissue, which surrounds the chief muscle bundle in equal thickness on all sides. It is permeated by many blood-vessels, by muscular and nerve strands, and also contains chromatophores and luminous organs.

The muscles of the arm can be divided into three distinct groups, viz., the central muscle bundle, the muscles of the suckers, and the muscles which serve as a connection between these two groups. The central muscle bundle consists of six longitudinal muscle strands, one transverse set of fibers, and six oblique or diagonal muscle strands. The musculature of the suckers consists principally of radiating fibers interspersed with circular muscles, the latter being more numerous in the musculature of the adhesive part than among the muscles of the sucking cavity. At the juncture of the adhesive part and the wall of the sucking cavity the circular muscles are especially well developed, forming a so-called sphincter. The connecting muscles connect the suckers with the central muscle bundle and also with the dermis (fig. 1).

Ballowotz ('93) made a closer study of the finer structure of the muscle fiber and found that it forms a narrow cylinder tapering at each end. This cylinder consists of spiral fibers and a granulated protoplasmic substance, which probably serves as a connection between the fibers and holds them together. 
The nervous system of the arm is quite complicated, and is composed of three distinct parts, viz., the central or axial nerve, the group of ganglion cells situated above each sucker, and the intramuscular nerves. The complex structure of the axial nerve has given rise to much scientific discussion. Van Beneden ('90), Cheron ('66), Owsjannikow ('95), and Kowalewsky claims that the axial nerve is a part of the peripheral nervous system, whereas Colosanti ('76), Uexkull ('93), and Guerin ('08) maintain that its qualities in structure, as well as in function, are such that it would easily be compared to a central nervous system. The three components of this complex axial nerve are: 1) a layer of ganglion cells; 2) a centrally located mass of nerve fibers, and, 3) two myelin cords running along the back of the arm. The ganglion cells are surrounded and supported by glia tissue. This tissue also forms a sheath around the processes of the ganglion cells and is present in the mass of centrally located nerve fibers (fig. 3).

Each arm is provided with one main artery embedded in the connective tissue, which lies between the two myelin cords. Two large veins (venae brachiales superficiales) running along the external side of the arm in the dermal layer, form the two main components of the brachial venous system. Little veins from the inner side of the arm convey the blood from the vicinity of the suckers to the two large afferent vessels. The blood of the Cephalopoda is a thin liquid containing only one kind of blood-corpuscles. The latter have some similarity to the leucocytes of the vertebrates. Kollman ('08) gave a detailed description of them (fig. 4). The blood has no fibrinogen.

\section{REGENERATION}

\section{A study of the external changes taking place during regeneration}

In the introduction attention has been called to the fact that the regenerative power of the octopus arm has been revealed by the discovery of many animals having regenerated arms. The authors who have reported on such specimens have also been mentioned. The embryonic development of the arm has 
up to the present not been made a subject of special study. There are several papers on the development of the Cephalopoda (Kolliker ('44), Grenacher ('74), Bobretzky ('77), Ussow ('74, '81), Viallton ('88)), but most of them treat only of the earlier stages or of the development of some particular organ, and none of them enter into a detailed account of the normal growth and development of the arm. Guérin has given a short sketch of the histological differentiation of the arm musculature, but does not mention the morphological changes which take place during the process of normal growth. A thorough and detailed report on the development of the arm has not yet been published. A. Naef's monograph on the development of the Cephalopoda (now being printed) will surely contain a detailed report on this subject.

The histological structure of the arm is the same at the base as at the distal end (with the exception of the tip, where the tissue is in an undifferentiated embryonic stage). I therefore did not pay great attention to the level of the cut or to the amount of the arm I severed from the proximal end. In the course of my experiments, however, it became apparent that the regeneration of arms cut off near the base required more time (in some cases two to three weeks passed before even the slightest sign of regeneration proper became visible). ${ }^{1}$ As my stay at the Zoological station at Naples was limited, I generally amputated only about one-third of the arm (rarely half of it), as I wished to have quite a number of specimens which were already in an advanced stage of regeneration. In cutting off the distal portion, care was taken that the section plane was as vertical as possible to the longitudinal axis of the arm. I was often surprised that no visible traces of blood could be found on the wound immediately after operation. In order to be quite certain on this point, I carefully dried the tentacle with a towel before cutting and then

\footnotetext{
${ }^{1}$ At the tip the tissues of the arm are still in an embryonic stage. Distal parts of the tip probably regenerate more quickly because they do not require so much time to transform their tissue into an embryonic blastema. The proximal parts probably require more time for this process, as their tissues are more differentiated.
} 
placed a piece of filter-paper on the wound immediately after the operation had been performed. I could not detect any moisture on the paper. This retention of the blood after amputation is in all probability associated with the ability of the arm to cast off distal portions by means of autotomy. According to Eisig and Riggenbach, Octopus de Filipi frequently casts off the greater portion of several tentacles in this manner. Riggenbach also mentions the ability of the octopodes to free their distally held arms, by simply casting off the held portion. I also observed similar cases of autotomy of the arm of Octopus vulgaris, but I believe that the ability to autotomize is confined to the distal portion. I was not able to find any portion of the arm which was modified or in any way arranged for autotomy. Neither do any of the numerous publications treating of the structure of the arm mention the presence of any mechanism especially adapted to autotomy. (It is a well-known fact that many arthropods are provided with such mechanisms.) Generally four-fifths of the arm is cast off. But this is not always the case, and the distance between the base of the tentacle and the point of rupture is by no means always the same. Riggenbach mentions some cases where this distance averages about $2 \mathrm{~cm}$., sometimes more, sometimes less.

Immediately after operation the external rim of the wound contracts spasmodically; this contraction is especially noticeable in the dermis. The external parts of the wound are thus covered, but the central musculature and the axial nerve remain unprotected. The axial nerve even protrudes beyond the surrounding tissues. Figure 5 shows a wound about one and a half hours after operation. The protrusion of the axial nerve is quite obvious. With the help of a magnifying glass I was able to see the myelin cords, the central nerve-fiber mass, and even the main artery quite plainly. This fact shows that this part of the wound was still without any covering whatever. Figure 6, showing a later stage (about ten hours after operation), presents quite a different picture. The dermis has contracted more closely over the wound, but has not succeeded in covering it completely. The axial nerve no longer extends beyond the 
surrounding tissues and its components are no longer visible, not even with the help of a magnifying glass. The hitherto unprotected portion of the wound has been covered by a substance, the nature of which could only be ascertained by means of a histological examination. This examination disclosed the fact that this covering consisted of blood. I am not able to state the exact amount of time which expires between the operation and the bleeding. However, I was able to detect blood only on such pieces which had been fixed five or six hours or more after operation. Pieces which had been preserved previous to that time showed no traces of blood. Here is a case where the section of blood-ressels is not immediately followed by bleeding, but where the bleeding takes place a considerable time after operation.

This, I think, is a fact which deserves notice. At first I thought that the blood which might have covered the wound at an earlier stage could have been washed away or that the animal bled from four to five hours before the bleeding stopped. But both these cases seem rather improbable. In the first place, I could not detect any moisture on the filter-paper which I placed on the open wound directly after operation; secondly, the conditions in which the Octopoda live would be very harmful to them if they were subject to prolonged bleedings from wounds in the arm. Brock believes that to a certain degree some relation between the oecology of the animal and the relatively great regenerative power of the arm exists. He wrote as follows:

Ohne die sehr nützliche Eigenschaft, die Arme schnell und vollständig zu regenerieren, würden die Cephalopoden wohl schwerlich die Konkurrenz mit anderen Mitbewohnern auf dem Riff aufnehmen können, trotz der unvergleichlich reichen Jagdgründe, welche es ihnen bietet. Es ist nicht schwer zu begreifen, dass Wohnorte von der Natur eines Korallenriffes den Armen eines Cephalopoden geradezu verhängnisvoll werden müssen. So kann es nicht überraschen, bei den Octopoden der Korallenriffe so häufig verstümmelten oder in verschiedenen Stadien der Regeneration begriffenen Armen zu begegnen. Von langarmigen Arten ist es überhaupt nicht möglich gewesen, ein Exemplar mit unverletztem Arm zu erhalten. 
Among the animals which were delivered to me for experimental purposes at Naples and Monaco, I also found a great many whose arms had been injured before capture, and quite a number of them showed advanced stages of regeneration. This shows plainly that the loss of an arm is by no means a rare or a dangerous occurrence. If, however, an animal, which is subject to frequent injuries on a certain part of its body, would each time bleed from five to six hours, the loss of blood would in the end probably prove fatal. The fact that the animals easily survive frequent injuries of their arms indicates the improbability of such prolonged bleedings.

It is difficult to explain the tardy appearance of blood on the wound. The only explanation I can give is the following: The minute the arm is cut off or cast off by autotomy the bloodvessels contract at the wound, later the muscles of the bloodvessels relax and allow blood to flow. The blood-corpuscles soon form a clot (agglutinate), and this clot serves as a preliminary covering for the wound.

Figure 7 which in comparison to figure 6 presents quite a different picture, exhibits a completely covered or closed wound. The time in which complete healing of a wound is achieved varies greatly. Some wounds were healed within less than twenty-four hours after operation, others showed no healing after thirty hours and were at that time only covered with a blood clot. The differences in the time necessary for the complete healing of the wound are probably caused by various factors. Generally a wound in the distal portion of the arm healed more quickly than one located in the middle or at the base. It is quite likely that the age of the animal also plays a part, for the wound healed more rapidly in a younger animal than in an older one. The season of the year may also have some influence on the progress of wound healing. In Naples, where I experimented in the spring, I found that the wound healing took less time than in Monaco, where I carried on my experiments in the fall of the year.

Figure 7 shows a perfectly smoothly healed arm stump. This smooth appearance is probably due to the wound's having been 
completely covered by epithelium. That the wound was actually covered by epithelium was proved by a microscopic examination of sections made of the piece in question. Another fact worth noting in this picture is the position of the two suckers at the obtuse end of the arm. These two suckers are somewhat drawn up as if they were also helping close the wound. This abnormal position of the suckers, which I observed as a regular occurrence during the process of wound healing, pushes the section plane out of its original position (vertical to the brachial axis) toward the exterior side of the arm. The suckers continued in this abnormal position for some time-in most cases from two to three days, in some cases ten days, and some even more. The same factors which cause the difference in time necessary for wound healing probably also play a part here: viz., location of the wound (distal or proximal), age of the animal, and season of the year. During my stay at Naples an octopus which measured a total length of $1 \frac{1}{2}$ meters was placed in one of the basins of the aquarium. Before its capture the animal had lost the greater portion (about three-fourths) of one of its arms, thus placing the wound in the proximal portion of the arm. The wound was completely healed and the two distal suckers were drawn up at the end in the abnormal position mentioned above. It required a period of three weeks before these suckers were again in their normal position.

As soon as the two last distal suckers regain their normal position, the first sign of a beginning regeneration becomes visible in the shape of a little knob, lying near the external side of the arm (fig. 8). Figure 9 shows a more advanced stage, the knob has already developed into a small process. On the interior side of this process a little groove becomes noticeable. This groove is plainly seen in figure 10 . The same picture also shows the formation of little transverse folds within the groove. These folds later develop into suckers. In the further course of regeneration the folds take a form similar to little warts (figs. 11 and 12). The cavity of the sucker and the adhesive part are formed later by means of invagination. The beginning of this process can already be noticed in the most proximal of the suckers shown 
in figure 11. All suckers are at first formed in the shape of little transverse folds arranged in single file. Later they are rounded off to little papillae. This process of rounding off seems to start in the center and progress sideward, so that the papillae are in quite a different position from the original folds. The latter were quite centrally located, whereas the papillae or warts have a lateral position. As the folds are rounded off alternately, once to the right and once to the left, the double row of suckers characteristic of the arm of Octopus vulgaris is thus gradually formed. But the above is only true of the suckers, which originate in the regenerated process. Attention has already been drawn to the fact that the regenerated process is attached to the external half of the arm. The process is considerably thinner than the stump of the arm, and in comparison to it looks like a thin lash-like appendage. Therefore, a considerable portion of the obtuse end of the stump remains free. On this free end the first regenerated suckers are formed in the shape of little transverse folds, but their further development differs somewhat from the development of the suckers located in the regenerated process. While the final double-rowed arrangement of the latter is already visible at an early stage of their development, the suckers of the free end remain arranged in single file till they are a great deal further advanced, and some of them even remain so permanently. The above is very well illustrated in figures 13 and 14. The four proximal suckers are arranged in single file and already show the invagination, which eventually leads to the formation of the sucking cavity and the adhesive part. Above these four suckers are ten to eleven newly formed suckers belonging to the regenerated process. These still show the form of papillae and are not nearly as well developed as the lower four, but their position already indicates their final arrangement in two rows. Above these papillae we can detect two to three small transverse folds arranged in single file. The latter are suckers at a very early stage of development.

How does the regeneration of the arm compare with its normal development? The arm of the octopus embryo can be divided into two parts-a rather thick proximal part, provided with 
three well-developed suckers (arranged in single file), and a distal part which compared to the proximal part is exceedingly thin. Naef has called this lash-like appendage a flagellum. The three suckers are arranged in single file and remain so permanently. In a more advanced stage the arm is provided with a larger number of suckers, of which the first three still are in single file, while the others are arranged in zig-zag fashion. Here we have an arrangement similar to that in figures 13 and 14 . So we may safely say that the arrangement of the first newly formed suckers in the course of regeneration does not differ greatly from the arrangement of the first suckers in the course of normal development. In regenerated parts, however, only one sucker remains permanently without a partner. In some cases I have found from two to three suckers arranged in this manner. The single sucker at the base of the regenerated part was to be found in even such advanced stages of regeneration where it was difficult to distinguish between the old stump and the newly formed part. Brock believes that this single sucker only appears after the lost part has been completely regenerated. On page 592 he speaks of it as follows:

Ist die Einschnürung (an der Amputationsstelle) bereits bis auf die Furche verschwunden, und geht der regenerierte Arm schon ganz unmerklich in den Stumpf über, so verrät sich der Vorgang der Regeneration noch lange durch eine mehr oder minder breite Lücke in der Reihe der Saugnäpfe gerade an der Amputationsstelle, welche erst ganz zuletzt von einem an dieser Stelle hervorsprossenden Saugnapf ausgefüllt wird.

Brock arrived at these conclusions through the study of several regenerated arms which he found on animals caught in the Indian Ocean. He never tried to prove his assertions by experiment. I should like to draw attention to the fact that never in the course of my investigations (and I had quite a quantity of material at my disposal) was I able to detect an interval in the row of suckers such as Brock both illustrates and describes. The sucker which Brock believes to be the last is probably identical with the single sucker at the base of the regenerated part (figs. 15 and 16). This sucker, however, is by no means the last, but 
on the contrary the very first sucker to be formed in the course of regeneration. Three or four weeks after operation, the first chromatophores appear in the regenerated part. They are lighter in color than the chromatophores of the arm stump. Figures 15 and 16 show regenerated pieces in an advanced stage of development. The only differences between the stump and the regenerated part consist in the different thickness and the different coloring of the chromatophores.

The arm of Eledone regenerates in the same way as the arm of Octopus vulgaris, with the exception that the suckers remain arranged in single file; this being their normal and permanent position.

I did not study the regeneration of the arm of the Decapoda very closely. I was able to observe the complete healing of the wound and the formation of a dome-shaped regeneration knob, ${ }^{2}$ but not able to follow up the development of the suckers, as the animals generally died before they reached this stage. Brock claims that the arms of the decapodes lack all ability to regenerate. As the arms of the decapodes are considerably shorter than the octopus arms, they are not subject to such frequent injuries. Nevertheless, the Decapoda are able to replace a lost arm; only the manner in which they do so differs from the way in which the octopus repairs the same damage. Doctor Naef showed me a sepia (at Naples) which had lost almost a whole arm. The animal had already begun to replace the lost part, but not by means of regeneration from the old stump, but by developing that rudimentary buccal $\mathrm{arm}^{3}$ which was correlated to the lost arm. This arm developed from a rudiment had the same structure as a normal arm and differed from the latter only

2 The regeneration knob of the sepia arm is centrally located, whereas the knob of the Octopus vulgaris is nearer the exterior side. No lash-like appendage or thin process is developed. The difference in thickness between the stump and the regenerated part is not so great. Perhaps the different arrangement and location of the myelin cords is the cause of this.

${ }^{3}$ The buccal funnel of the decapods is a set of rudimentary arms and corresponds to the inner circle of arms of the Nautilidae. The buccal funnel of the decapods possesses seven to ten rudimentary arms, which, according to Naef, are provided with two rows of suckers. 
in length (it was shorter) and in its position nearer to the buccal funnel. In the further course of development this arm would probably have replaced the lost one. This case would indicate that sepia does not always renew the lost part of its arms by direct regeneration, but in some cases resorts to compensatory regulation to replace the lost organ.

\section{A histological study of regeneration}

The course of regeneration which takes place after injury can easily be divided into three distinet stages, viz., the healing of the wound, the degeneration of the tissues, and the renewal of the same. However, I wish to draw attention to the fact that these histological processes need not necessarily follow each other in the same order as here mentioned.

a. Wound healing. It is not possible to detect many changes in the wound shortly after operation. The only obvious alteration consists in a contraction of the edges of the wound, by which they form a kind of raised rim around the same. The greater part of the wound with the exception of the axial nerve is in some degree protected by this rim. The histological examination showed that the raised rim was formed by the connective tissue of the dermis, in its endeavor to contract over the wound. However, only the externally located muscles are covered by the connective tissue, while the center of the arm, comprising the axial nerve with its surrounding connective tissue layer and the inner muscles, remain unprotected. Figure 17, which shows a longitudinal section through the center of an arm one and one-half hours after operation, illustrates these conditions. Only the external portions of the wound are covered, and the axial nerve even protrudes beyond the surrounding tissues. The only alteration visible in the tissues immediately adjacent to the wound is a slight disintegration in the inner transverse muscle in the central mass of nerve fibers (neuropil) and in the ganglion layer. This subject will be considered below (pp. 22 and 27). The main brachial artery is closed. It is hard to tell whether this is a natural condition or one produced by fixing The artery 
contains some blood in its most distal portion, most of which consists chiefly of blood-corpuscles without plasma. Cuénot claims that such blood-corpuscles are degenerated. All the blood-vessels leading toward the wound contain very little blood, nor is there any trace of blood on the wound itself. I believe that up to the time at which this piece had been fixed, no bleeding had yet taken place. The reasons which led me to have this opinion have been discussed in the previous chapter (p. 8). Young stages of regeneration (such as are shown in fig. 17) are always open, no covering or closing of the wound having yet taken place.

Techow ('10) found that the wounds of the gastropods were provisionally closed by a clot which was formed by the contents of the blood-vessels. I found that the wounds of the Cephalopoda were closed in the same manner. About five or six hours after operation all blood-vessels leading to the wound are filled with blood, which after leaving the vessels spreads over the wound, thus forming a protective covering for the same. Attention has already been drawn to the fact that the blood of the Cephalopoda contains no fibrinogen (p. 5), therefore the clot which preliminarily closes the wound cannot be formed through blood coagulation, as is the case in wounds of vertebrates and arthropods. The wound can only be closed by the agglutination of the blood-corpuscles, and a histological study of the sections proved this to be the case. In agglutinating the bloodcorpuscles form a kind of network (figs. 19, 20, and 21). In many other invertebrate animals the wounds are also closed by means of blood- or lymph-corpuscles. Techow ('10), Hanko ('13), " Cucagna ('15), and Nusbaum ('15) found it so for the Mollusca. Hescheler ('98), Nusbaum, and Friedländer ('95) claim that wounds of worms are closed in the same manner. Ost ('06), Friedrich ('06), and Reed ('05), who have studied the regeneration in Arthropoda, found that the wounds of these

\footnotetext{
${ }^{4}$ Hanko studied the regeneration of Nassa mutabilis and speaks of blood coagulation as a means of closing the wound. This is probably an erroneous statement, for, according to Kollman, the blood of the gastropodes contains no fibrinogen, therefore coagulation is not possible.
} 
animals are also closed by the agglutination of the leucocytes, but the agglutination is accompanied by blood coagulation, as the blood of the Arthropoda contains fibrinogen. The leucocytes of the Cephalopoda do not undergo any great change during agglutination. I could not observe any formation of pseudopods such as Loeb ('09) and Geddes ('01) describe. The only alteration which I could discover in the blood-corpuscles was hyalinosis resulting from the disappearance of a great number of granules. The change wrought by hyalinosis can be plainly seen in comparing figures 4 and 19 . The blood-plasm seems to disappear soon after the bleeding stops, for I could not find any trace of it on most of the sections. Were it, not for a few cases such as one exhibited in figures 19 and 22, where blood plasm is still present, one could easily suspect that the plasm flows away immediately after leaving the blood-vessels. If we examine the plasm in the blood-clov closely, we can detect a difference between it and the plasm in the blood-vessels. In the first place, the plasm of the clot is not as uniform in structure as the plasm in the blood-vessels, and, secondly, it does not stain the same intense brown-red, when the combined stain of Heidenhain and eosin is employed. But in spite of these differences, it still retains the character of blood-plasm. In some sections made of pieces which had been fixed after a period of five hours after operation, I even found the plasm of the blood-clot almost identically the same in appearance as the plasm in the bloodvessels. Gradually the blood-plasm entirely disappears from the cicatricial tissue. As no signs of degeneration were visible, the plasm probably becomes absorbed, but unfortunately, I was not able to find out how this is done. After the disappearance of the blood-plasm the cicatricial tissue looks like a very close network of thin threads, in which numerous nuclei are embedded (figs. 20 and 21). The fact that these nuclei increase in numbers would indicate that they multiply. Migration of nuclei from the subjacent tissue is not likely, for the cicatricial tissue is separated from all tissues, with the exception of the musculature, by a very distinct boundary line. The muscles; however, being in a state of degeneration, which begins before 
the formation of the blood-clot, cannot possibly contribute cells for the tissues covering the wound. The increase in the number of nuclei must be the result of nuclear division. In spite of careful search, I was not able to find any mitosis. The nuclei probably multiply by means of direct or amitotic division.

The cicatricial tissue which is formed by the agglutinated blood-corpuscles is never cast off, but retained. The same may be said of the cicatricial tissue of the Pulmonata, Nudibranchia, and Prosobranchia. Several authors have been able to establish the same facts for worms. The wounds of the Vertebrata and the Arthropoda (with some exceptions), however, heal under a scab of coagulated blood. The scab soon degenerates and is cast off as soon as the healing has been accomplished.

In time the leucocytes, which constitute the cicatricial tissue, become more and more hyalin. The granules, which were at first equally distributed in the protoplasm, gather around the nucleus and along the cell wall and finally disappear. The cells change their shape-formerly round, they now become elongated. At the same time the nucleus also becomes elongated. At times this alteration begins in the most superficial layers of the cicatricial tissue, but the study of a greater number of sections showed that generally the most exterior cells retained their round shape longer than those below the surface, the latter becoming elongated very soon (figs. 20 and 21). These changes take place in the cicatricial tissue before it is covered by epithelium. Hescheler, Friedländer, and Rievel found similar elongated spindle-shaped cells in the cicatricial tissue of worms. Friedländer and Rievel claim that these cells are evolved from leucocytes, whereas Hescheler doubts it. What finally becomes of this cicatricial tissue? There are two points worth notice in connection with it. In the first place, I was never able to find any sign of degeneration in this tissue, and, secondly, the regenerating epithelium does not grow under or through it, but covers it. Both these facts show plainly that it is retained and not cast off. It therefore may be called a blastema, and in order to distinguish it from the second blastema, which appears later and consists of neuro- and sarcoblasts (fig. 31), I would designate 
it as primary blastema. As this blastema does not degenerate, it is used to supply the material for some regenerating tissue. It is not likely that the primary blastema contributes any material for the construction of the nerves or muscles, for the nuclei of the primary and second blastema differ greatly in structure. The nuclei of the former are generally elongated and provided with several nucleoli, the nuclei of the latter are larger in size, round in shape, only have one nucleolus, and show a greater affinity for staining agents. All these differences indicate that it is quite impossible for the nerves or muscles to draw any material for their regeneration from the primary blastema. However, it is very likely that the primary blastema contributes a great part of its material to the construction of the new connective tissue, especially the dermal layer. There are two facts which further strengthen this theory. First, the similarity of the nuclear structure and, secondly, the fact that the primary blastema is dislocated by the second blastema's being pushed sideward, so that it gradually occupies the place of the dermal connective tissue. Most of the papers dealing with the subject of regeneration do not definitely state what ultimately becomes of the cicatricial tissue. This applies to the three papers heretofore written on the regeneration in Mollusca. Nusbaum and Cucagna ('15) mention the presence of connective-tissue cells in the cicatricial tissue before the same is covered with epithelium, but they do not mention the origin of these cells. Even though the literature treating of regeneration in worms is very voluminous, I was not able to find very much information on the further utilization of the cicatricial tissue. Many authors never even mention its presence. Others explain its formation, but do not say what becomes of it later. Friedländer intimates that muscle fibers might arise from the cicatricial tissue, but does not state this as an actual fact. Rievel, who believes that the cicatricial tissue (he calls it granulation tissue) has its origin in the mesoderm, claims that later it becomes mesenchymatous and finally forms the unstriated muscles. According to Hescheler, the cicatricial tissue becomes fibrous (in the course of regeneration) and arranged in layers which run parallel to the front external 
contours of the body, occupying a place which would naturally be filled by the continuation of the longitudinal muscles.

As the cicatricial tissue of the animals whose blood contains fibrinogen soon becomes scabby and is cast off, it is quite natural that most of the publications on the regeneration in vertebrates and arthropods do not give any great attention to the cicatricial tissue. This applies almost without exception to all the reports on the regeneration in arthropods. Among the many authors who have studied the regeneration of vertebrates there are a few who point out that not all of the cicatricial tissue is merely a preliminary covering for the wound, but that some of it at least is utilized for some future purpose. Aufrecht ('90), Billroth, and Rindfleisch claim that the leucocytes enclosed in this tissue are the origin of connective-tissue fibers. Among the more recent reports on this subject I should like to draw attention to a paper published by Baitsell ('16). This paper treats of the processes connected with the healing of skin wounds in frogs. Baitsell points out that the blood-clot formed by the coagulation of the blood acts as a kind of connective tissue for the time being by holding the edges of the wound together. He found that the coagulated blood formed a typical fibrin net. Later on this net was changed into a fibrous tissue, consisting of separate fibers and fiber bundles. This alteration was affected in a few days' time. This change could not be traced to the activity of any other cells, as it took place before any connective-tissue cells had migrated into the blood-clot. The new tissue had the appearance of regenerating connective tissue. It soon exhibited the same reactions to staining agents as the old connective tissue, but differed from the latter in its attitude toward pancreatin, as it was digested by it. Baitsell points out that embryonic connective tissue is also digestible by pancreatic juice. The summary of all these reports shows that the theory according to which connective tissue is evolved from cicatricial tissue has already been advanced by several investigators. The blastema is separated from the subjacent tissues by a well-defined boundary line, only where it touches the musculature does this line disappear, and the tissues seem to pass into each other. 
When a short distal piece is amputated, very little blood leaves the blood-vessels. In such regenerations there is little primary blastema (fig. 23).

In his study of the regeneration in Gastropoda, Techow describes processes very similar to those which I have just depicted in Cephalopoda. He found that the wound remains open without any covering whatever during the first few hours after operation. Then the blood-vessels leading to the wound become filled with cells, which later form a layer over the wound. Techow gave a detailed description of these cells, but did not classify them histologically. In my opinion, these are haemolymph cells, for it would be rather strange for the blood-vessels to be suddenly filled with a great number of cells which normally did not belong there. An appearance of strange cells in the blood-vessels would denote a pathological condition. But these cells later on form a blastemal tissue, so they cannot be pathological. These cells cannot be anything else than blood-corpuscles, and from Techow's paper we can clearly see that Gastropoda, like the Cephalopoda, do not bleed immediately after operation, but only after a period of several hours has elapsed.

During the formation of the cicatricial tissue, which acts as a preliminary covering for the wound, the epithelium which is destined to form the final covering remains inactive. It is difficult to state just how much time must elapse after operation before the regeneration of the epithelium is initiated. It varies from ten hours to two days. The causes of this fluctuation are probably the same as already mentioned on page 9. Before the epithelium begins to stretch over the wound, the basal membrane of the uninjured epithelial cells immediately adjacent to the wound draws back a little. According to Hescheler, the same thing happens before the regeneration of the epithelium in Lumbricidae. The cells from which the basal membrane has withdrawn are no longer in such close connection with the more proximal epithelial cells, and probably on that account able to aiter their form. They become flat, and their nuclei, which formerly were vertical, are now in horizontal position. Figure 24 shows a picture of such horizontal nuclei. These 
flat epithelial cells then proceed to crawl over the wound until the latter is entirely covered by an exceedingly thin epithelium, which seems almost no thicker than a membrane. The nuclei, however, are easily visible and the cuticle shows the characteristic striae. I could not detect any nuclear division at this stage. Here we have a case of rearrangement of old material, which is generally called morphalaxis. Cucagna and Nusbaum found that the final healing of wounds in Nudibranchia was accomplished in the same manner. Lang, Hescheler, and Stevens ('06) state that the same is the case in worms, but Techow and Hanko, who both worked on Gastropoda, claim that mitosis takes place in the epithelium while the latter spreads over the wound. The cells of the newly formed epithelium vary greatly in shape (fig. 24). Sometimes they are long, sometimes short and broad. Some of them are funnel- or pear-shaped, and others again have appendages extending into the subjacent tissue. In general the epithelial cells are larger than the cells of the adjacent tissue. The variety of form among the young epithelial cells is perhaps due to the absence of the basal membrane. The absence of such a membrane permits the direct connection of the epithelium with the subjacent embryonic tissue. This makes it possible for cells of this tissue to migrate into the epithelium in order to increase more rapidly the rather small number of its cells. But in spite of very careful search, I was not able to find a single case of such migration. Wound healing having been accomplished, the epithelial cells, which constitute the covering, undergo a change. They no longer remain flat, but become cubical, and their nuclei regain their former vertical position, at the same time growing more voluminous. At this stage the young epithelial cells begin multiplying by means of nuclear division. This activity is not confined to a certain part, but spreads all over the young epithelium. The division is so rapid that the new epithelium is soon filled with a large number of nuclei, and on the third or fourth day after operation looks like a syncytium (fig. $26 \mathrm{a}$ ). There are relatively a greater number of nuclei in the new epithelium than in the old. As I could not find any cases of mitosis, I am inclined to think that the increase in the 
number of nuclei is due to amitotic or direct division. This opinion was confirmed by the discovery of several nuclei in different stages of amitotic division (fig. 26 b). Lang ('09, '10) found that the epithelium of the Turbellarians also regenerates by means of Amitosis. Techow, however, claims that the increase in epithelial cells of the Gastropoda is due to both mitotic and amitotic division.

At the time when this lively nuclear division of the epithelium begins, the latter is already provided with a well-developed basal membrane. It is difficult to say where this membrane has its origin. It is possible that the subjacent tissue takes an active part in its formation. The presence of a basal membrane probably prevents any epithelial cells from migrating into the subjacent tissue. At any rate, I could not find any such cases of migration. In this point the epithelium of the Cephalopoda differs greatly from the epithelium of the Gastropoda. According to Techow, the latter contributes cells to the subjacent tissue, this being made possible by the tardy appearance of the basal membrane (it took eight days before it was formed).

b. The muscles. Soon after operation disintegration sets in in those muscles immediately adjacent to the wound. This is due to a degeneration of muscular tissue, which comes to pass in the following manner. The sarcoplasm breaks down, the spiral fibers seem to expand or grow thicker, thereby filling the gaps left by the decaying sarcoplasm, and crowding out the granulated plasm of the core (fig. 27). In spite of this degeneration, the muscle fibers still stain deeply when eosin is employed. Later on in the course of further degeneration the colorability decreases, the axial tube disappears, and the muscle fiber loses its cylindrical shape. In the end all that is left of the muscle fiber is a clotty mass, which stains very slightly.

The nuclei of the muscle fibers do not all degenerate in the same way. In some the disintegration becomes noticeable in the chromatin, the latter massing together in little lumps, but the exterior form of the nucleus is not changed during this process, neither were there any visible signs of shrinkage. In other nuclei the shrinkage and the concentration of the chromatin seem to 
take place simultaneously; at any rate, they alter their form, appearing round instead of elongated. These two processes continue until the nucleus has the appearance of a solid mass of chromatin. Then it breaks up into two, sometimes three parts, a process which has been called fragmentation (fig. 28). These nuclear fragments probably have great qualities of resistance, for they endure the whole process of degeneration, are present in its very first stage, and are still visible when the tissue has become quite necrotic. I was not able to find any phagocytic formations consisting of sarcoplasm and parts of the nucleus, such as Metchnikoff ('92) discovered in the degenerating muscles of vertebrates. Neither was I able to detect a fatty degeneration which Bordage ('14) found to be the case in the muscles of Orthoptera.

Soon after the wound has been covered by blood, corpuscles from the blood-clot migrate into the degenerated muscles and begin to dissolve and absorb the disintegrated parts. The cloddy remnants of the muscles, which up to the appearance of the blood-corpuscles, consisted of a solid mass, begin to disintegrate, and at the same time the nuclear fragments (described above) decrease in number (fig. 29). Finally so many bloodcorpuscles collect in the degenerated muscle tissue that the latter appears like the primary blastema and is hardly to be distinguished from it.

The first sign of regeneration in the muscle tissues is the appearance of large cells, which have very little protoplasm and seem to consist only of a large nucleus (fig. 30). These cells first appear in that part of the blastema which occupies the place formerly filled by the degenerated muscles. These cells are most probably sarcoblasts, and like the sarcoblasts of the vertebrates originate in the old muscle tissue. It is difficult to give any exact information as to how they are formed or as to whether the whole muscle fiber or only a part (and which part) contributes the necessary material. But there can be no doubt about their actually being sarcoblasts, for their development into muscle fibers can easily be followed up in later stages. The sarcoblasts have a rounded or oval nucleus containing very fine granules 
and one nucleolus. They migrate to the distal portion of the wound, and in combination with the neuroblasts form the second blastema (fig. 31). They multiply very rapidly by means of mitosis (fig. 32). About twelve to fourteen days after operation the sarcoblasts of the proximal portion of the regenerated piece begin to transform into the definitive muscle fibers. But this differentiation does not begin simultaneously in every part of the musculature. The longitudinal muscles are the first to begin this process, and in these the very first differentiation takes place in those parts which are nearest to the perimuscular connective-tissue membrane. The differentiation progresses distalward in the longitudinal muscles. The transformation of the transverse muscles into their final form probably takes more time, for they are still in the sarcoblast stage at a time when the surrounding longitudinal muscles already appear as quite well-developed muscle cells. Most likely this is due to the different intensity of growth in the different muscle fibers. The muscle fiber can only grow by means of sarcoblasts. The best proof of this assertion is the fact that at the distal end of every regenerated piece as well as of every normal arm there are no muscle cells, but only sarcoblasts. As the difference in thickness between the regenerated piece and the stump is particularly great at the juncture of these two parts, there must be an active and intense growth in breadth at this point, in order to equalize this difference in thickness. The transverse musculature will probably take an active part in this growth. Whereas in the longitudinal muscles the point of active and intense growth is always carried farther and farther away from the juncture the more the regenerated piece grows in length, the transverse muscles of this part remain in a stage of active and intense growth for a much longer time. Hence the transformation of the sarcoblasts into muscle fibers begins later in the transverse muscles than in the longitudinal muscles. That the sarcoblasts of the Cephalopoda are a product of the old muscle fibers has already been mentioned. This is a case of new formation from preexisting tissue and verifies the statement that a new tissue can only be formed by the same kind of old tissue. According 
to Techow, however, this rule is not applicable to the muscles of the Gastropoda. He claims that in the course of regeneration the new muscles are also evolved from large cells (sarcoblasts), but believes that these cells are originally epithelial cells which have migrated into the subjacent tissue. There are very few reports on the histological processes connected with the muscle regeneration in Mollusca. I could only find three in all-Techow's, Hanko's, and the paper published by Cucagna and Nusbaum on the regeneration in Nudibranchia. Techow's opinion on the subject has already been given. Hanko claims that the new muscles are a product of the old, but he does not mention the presence of any sarcoblasts. He states that certain cells (Wanderzellen), whose origin he does not explain, gather around the distal and somewhat inflated end of the muscle stump. These cells form a kind of bridge between the muscle stump and epithelium, and along this bridge the new muscle fibers, which are formed by proliferations of the old, develop. According to Cucagna and Nusbaum, the new muscles are evolved from sarcocytes (sarcoblasts) formed of the sarcoplasm and nucleus of the old muscles. Schultz, Bordage ('14) and Friedrich state that the same is true of the muscles of the Arthropoda.

Barfurth ('91), Nauwerk ('90), and Fraisse ('86) found that the muscles of the vertebrates also regenerate by means of sarcoblasts.

The musculature of the suckers is formed by lateral proliferations of the central muscle bundle (fig. 33). These buds are soon separated from their seat of origin by connective tissue. The invagination of external tissue which causes the formation of the sucking cavity also indents the muscle-bud, consisting of sarcoblasts. In the course of further development the sarcoblasts are grouped around the cavity in two distinct parallel layers (fig. 34). Later these sarcoblasts develop into the radiating and circular muscles of the sucker. As in the transverse muscles, the formation of the final muscle fibers begins later in the sucker muscles than in the longitudinal muscles of the central muscle bundle. 
c. The nervous system. Up to the present no histological study of nerve regeneration in Mollusca has been published. Techow refrained from doing so on account of technical diffculties. Hanko states that the nerves which innervate the eye of Nassa mutabilis regenerate, but does not state how. He refers to a paper by $M$. Küpfer which was in preparation when his own was published. I tried to obtain this paper, but as it has not yet been published, I was unable to see it. Nerve regeneration in worms has been studied by Lehnert, Bardeen ('04), Hescheler, Lang, Flexner ('98), Schultz, and Stevens. The two first authors claim that the new nerve fibers simply grow out of the old. Lang, Flexner, Schultz, and Stevens found that the new brain is formed by parenchym cells. The regeneration of the nervous system of vertebrates has often been made the subject of histological study. Experiments were made chiefly on the spinal cord of tritons and lizards, in some cases on the spinal cord and also on the brain of birds (pigeons) and mammals (rabbits and dogs). Dentan ('73), Eichhorst ('75), Naunyn ('74), Keresztzsegy ('92), and Hanns ('92) could not find any regeneration in the central nervous system of vertebrates. Ströbe ('94) claims that the injured spinal cord of the rabbit makes an effort to repair the damage, but that an actual regeneration does not take place. Contrary to this, Walter ('53), Cattani ('85), Brown-Sequard ('50), Müller ('64-'65), Masius ('70), and van Lair ('70), Caproso ('88), all claim that the central nervous system is able to regenerate. 'Tedeschi ('97) found regenerated ganglion cells and nerve fibers in the brain of mammals. There is quite some diversity of opinion on the manner in which the nerve cells multiply. Walter, Cattani, Modino ('85), Friedmann ('88), Ziegler ('95), Coen ('88), Sanarelli ('96), Marinescu ('94), and Tedeschi, all claim that the nerve cells multiply by means of mitosis. Caproso and Barfurth, on the other hand, believe that the new nerve cells are evolved from neuroblasts, which originate in the epithelium of the central canal. Mühlmann ('08, '10), who has made the structure and growth of the nerve cell an object of special study, is of the opinion that already at an early stage of its development certain 
inhibiting elements appear in the nerve cell which prevent its further division. In the following I shall try to give a short histological study of nerve regeneration in the arm of Octopus vulgaris.

An examination of the wound with a magnifying glass immediately after operation reveals the fact that the axial nerve protrudes beyond the surrounding tissues (fig. 4). H. Müller found similar conditions in the spinal cord of a lizard whose tail had been amputated. An intense and active degeneration is initiated in the protruding part of the axial nerve. This disintegration progresses so quickly, that it is very difficult to make a thorough examination of its various stages. It begins in the layer of ganglion cells. The first signs of degeneration become visible in the nucleus. The chromatin, which in the normal nucleus is generally thickest along the periphery, moves toward the center and gathers around the nucleolus, the nuclear membrane still retaining its original form while this process is going on (fig. 35). Later on this membrane also degenerates, and the nucleus, which has in the meantime shrunk to a homogeneous little lump, lies in a kind of vacuole. Most of these nuclear remnants soon disappear, but some of them seem to be endowed with a great power of resistance, as they are still present even after a few days. I was not able to observe carefully the degeneration of the protoplasm. On the whole, I found the endoplasm resisting longer than the ectoplasm. The nuclei of the glia tissues shrink and are changed into homogeneous chromatin globules, resembling the reduced ganglion-cell nuclei, only somewhat smaller in size. The degeneration in the neuropil is at first not as marked as in the ganglia layer, and is only noticeable by a slight disintegration of the tissues. When stained with eosin, the neuropil no longer exhibits the same intense coloring as before, and the glia nuclei distributed in it have noticeably shrunk. The fibers of the myelin cords are swollen and unduly enlarged at the distal end of the stump. Sometimes they are from four to six times as voluminous as the normal fiber. The myelin, which in the normal fiber is so equally distributed as to give it a homogeneous appearance, 
clots together to granules which either form a network or larger lumps of granules (fig. 36). Ströbe found that the white substance of the spinal cord of vertebrates also swells up as a result of degeneration. This fact would to a certain degree strengthen Colosanti's assertion that a kind of analogy existed between the myelin cord and the white matter. The degeneration reaches deeper into the myelin cords than into the ganglia layer and the neuropil.

About ten hours after operation a further disintegration is noticeable in the myelin cords and the neuropil, whereas the ganglion cells show hardly any further change. There is a marked increase in the number of nuclei in the neuropil as well as in the myelin cords. In the myelin cords this increase is due to the migration of blood-corpuscles. The fibers of the myelin cords are torn asunder, the myelin cords thus occupying more space at the distal end than is normally the case (fig. 23). Probably the blood-corpuscles also migrate into the central mass of nerve fibers, but I could not ascertain their presence there with absolute surety. The increase in the number of nuclei in the neuropil is due to the amitotic or direct division of the glia nuclei, which have entered the central nerve-fiber mass along with the processes of the nerve cells (fig. 37). About one or two days after operation a large number of cells, all provided with vesicular nuclei, appear in the neuropil and then migrate to the most distal part of the stump. Together with the sarcoblasts they form the so-called second blastema (fig. 31). These cells are doubtlessly neuroblasts, for later on the ganglia are evolved from them. It is very difficult to find the origin of these neuroblasts. I am of the opinion that the glia nuclei contribute largely to their formation, for the glia nuclei are the only nuclei (besides a few nuclei of the connective tissue), which are normally embedded in the central mass of nerve fibers. But I must also draw attention to the fact that the nuclei of the neuroblasts are a little larger than the glia nuclei. The neuroblasts are very similar in structure to those ganglion cells lying nearest the neuropil, which have been described as nude nerve nuclei. Perhaps these cells having been 
stimulated to division by the operation, have multiplied and migrated into the central nerve-fiber mass. Some neuroblasts also originate in the layer of ganglion cells. It is hard to tell whether they are evolved from the glia or produced by the nerve cells. If the latter is the case, we may safely say that only the small ganglia, the so-called nude nerve nuclei, take part in the production of neuroblasts. These small ganglia are probably in a very early stage of differentiation. Therefore they are more like the neuroblasts than the medium-sized or larger ganglia. But in spite of their similarity, I would not say that the small ganglia and the neuroblasts are identical. I was never able to discover any mitosis in the small ganglia, whereas the neuroblasts exhibited many cases of karyokinesis. The large and medium-sized ganglia do not participate in the production of neuroblasts. Neither a division nor a reduction of the protoplasm (a process which would bring them in closer relation with the neuroblasts) takes place. It is quite probable that both the glia and the small nerve cells produce the neuroblasts. The neuroblasts are very similar to the sarcoblasts, which makes it difficult to tell them apart (fig. 31).

Fine fibers of the myelin cords grow into the second blastema, thus separating the neuroblasts from the sarcoblasts of the externally located muscle bundle. The myelin cords do not change their appearance very much during regeneration. They do not undergo such a radical change as the rest of the tissues. Their alteration, due to degeneration, has already been mentioned (p. 27), and the only change caused by regeneration was an increase in the number of nuclei of the sustentacular tissue. In consequence of this remarkable behavior, they are more easily and rapidly recognized in the regenerated piece than any of the other parts, with the exception of the epithelium, the main artery, and the two venae superficiales. The myelin cords grow into the regenerated piece, not in the form of blastema cells of any kind, but as a well-differentiated tissue. Many authors have put forth the theory that regeneration is in a large degree dependent on the presence of nerves. The fact that the myelin cords, which serve as a connection between the brain 
and the axial nerve, grow so quickly and appear as differentiated myelin fibers in the most distal portion of the regenerated piece, while all the surrounding tissues are still in blastemal stage, is a strong argument in favor of this theory. On the inner side of the myelin cords the neuroblasts form the same regular rows as the ganglion cells in the normal arm. Eleven days after operation this regular arrangement and also the tissues separating these rows were visible. The first sign of the new central mass of nerve fibers also appears at the same time. The myelin cords probably produce the first fibers of the new neuropil, for the young nerve cells do not at this time exhibit any processes. Only later are the neuroblasts turned into ganglion cells by forming protoplasm and fibers. As the differentiation of the ganglia progresses, the neuropil naturally gains in size. Three weeks after operation the axial nerve is well developed in all of its three components (fig. 38). Among the ganglia the small cells, the so-called nude nerve nuclei, predominate. But there are also quite a number of medium-sized nerve cells present, whereas large ganglia are still missing. The latter probably appear very late, for I was unable to find any, even in regenerated pieces, which were already in quite an advanced stage. The young neuropil contains relatively many nuclei, which, however, decrease in numbers as development goes on. The greater part of the regenerated piece is occupied by the axial nerve, the rest of the tissues being confined to a relatively small space. The same conditions prevail in the embryonic arm. In the normal arm the axial nerve constitutes a fourth part of the whole. ${ }^{5}$

Unfortunately, I was not able to observe the formation of the sucker ganglia and the four nerve cords embedded in the muscles. The sucker ganglia probably appear very late in the regenerated piece, for I was not able to find a single one. I believe their formation is only initiated after the nerves which connect the axial nerves with the sucker ganglia and also innervate the suckers have grown out from the axial nerve. It is

- I should like to draw attention to the publications of Brynes and Fritzsch. Both of them studied regeneration in water newt (Triton) extremities and found that cartilage is evolved from blastema directly opposite of the growing nerve. 
possible that the ganglia arise in the embryonic connective tissue under the influence of the growing nerve. In a piece which had been fixed three or four days after operation and which was just on the point of beginning regeneration, I was able to observe fine fibers of the peripheral nerves, which originated in the uninjured part of the axial nerve, but innervated one of the amputated suckers growing into the primary blastema. At the distal end of one of these fine fibers I could detect some cells which showed a marked similarity to the nerve cells (fig. 39 ). ${ }^{5}$

The subcutaneous connective tissue is most probably evolved from the primary blastema. At first, however, the latter is separated from the subjacent connective tissue by a sharp boundary line, which later on disappears. Unfortunately, I am not able to give any detailed account of the regeneration of the vascular system. I heard that Minervini had studied this process, but I was not able to find his publication. Authors who have studied the regeneration of the vascular system in other animals claim that the new blood-vessels are formed by a proliferation of the endothelium of the old blood-vessels. I was not able to detect any proliferation of endothelium in the regenerating arm of the Cephalopoda. The main artery and the veins grow rapidly and are visible in the most distal portion of the regenerated piece. In such a stage as is exhibited in figure 8 the blood-vessels form a kind of plexus which is well filled with blood.

I did not make the regeneration of the epithelial glands and the chromatophores the subject of any closer study. Chun has published a very detailed account of the development of the chromatophores.

\section{SUMMARY}

The most important morphological changes which occur during the regeneration of the arm of the Cephalopoda (Octopus vulgaris) are the following:

1. Wound healing. After operation the edges of the wound curl inward. The axial nerve protrudes beyond the other tissues. Bleeding does not take place immediately after operation, but 
after a period of several hours (five to six). The wound is then completely overspread with blood which serves as a preliminary covering for the same. After bleeding, the protrusion of the axial nerve disappears. The last two suckers at the obtuse end of the arm are abnormally drawn up, as if they also participated in the preliminary closing of the wound. The final wound healing by epithelium occurs in some animals within the first twentyfour hours after operation; in most cases, however, it takes from thirty-six to forty-eight hours.

2. Change of form. The distal suckers which were drawn up regain their normal position. The first visible sign of regeneration appears in the shape of a little knob near the external side of the arm. The knob develops into a little lash-like appendage, which appears like a thin rod in comparison to the arm stump.

3. Formation of the suckers. The newly formed suckers must be divided into two groups, those that are formed as suckers of the regenerated piece proper and those formed at the obtuse end of the arm stump. All suckers first appear in the form of little transverse folds. Later on they are rounded off to little papillae. The newly formed suckers at the obtuse end of the arm are arranged in single file. They remain in a single row during the greater part of their development. On the other hand, the suckers of the regenerated piece exhibit the final double-rowed arrangement at a very early stage of their development. The sucker cavity and the adhesive part are both formed by invagination. At the base of the regenerated piece, one or two suckers (sometimes three) always remain in single file.

4. The chromatophores. The first new chromatophores appear about three to four weeks after operation. They are smaller and of a lighter shade than the normal chromatophores.

The histological study led to the following results:

1. Wound healing. The wound is at first unprotected (five to six hours). Then a preliminary covering, consisting chiefly of a clot of agglutinated blood-corpuscles, is formed. From this blood-clot a primary blastema is gradually evolved, the blood-plasm becoming less and less, and the agglutinated bloodcorpuscles forming a fine network. The epithelium remains 
inactive for the first few hours after operation. Later on the epithelium cells at the edge of the wound grow flat, the nuclei which up to that time were vertical change their position, becoming parallel to the edge of the wound. The flat cells creep over the wound from all sides, till the latter is completely covered by a very thin tessellated epithelium, provided with a cuticle. The tessellated epithelium gradually becomes cubical and later on cylindrical.

2. The musculature. Disintegration begins in the musculature soon after operation. The sarcoplasm degenerates. The spiral fibers expand, thus filling the gaps left by the sarcoplasm, and at the same time narrowing the central duct and crowding out the granulated substance of the core. The result of this degeneration is a cloddy mass, which shows less affinity to staining agents than the normal muscle fiber. The nuclei become homogeneous globules of chromatin, and break up into two or three pieces (fragmentation). The degenerated muscles are partly dissolved or absorbed by blood-corpuscles which migrate into the disintegrated tissue. The muscles regenerate by means of sarcoblasts. The sarcoblast possesses quite a large nucleus, which is provided with one nucleolus. The sarcoblasts later migrate to the distal part of the stump, and in combination with the neuroblasts form the second blastema. They multiply by means of indirect or mitotic division. The sarcoblasts of the external longitudinal muscles are the first to exhibit muscle fibers. In the transverse muscles fibers appear at a much later date. The muscles of the suckers are evolved from lateral proliferations of the sarcoblasts of the central muscle-fiber bundle.

3. The nervous system. The first sign of disintegration of the axial nerve is found in the layer of ganglion cells. The ectoplasm of these cells degenerates and the nucleus shrinks, the chromatin gathering around the nucleolus. The nuclei of the neuroglia undergo the same change. The fibers of the myelin cords expand and often grow five times the size of the normal tissue. The only signs of degeneration visible in the neuropil are the shrinking of the neuroglia nuclei embedded there and a decrease of its 
affinity to staining agents. Later the neuropil becomes vacuolized and the neuroglia nuclei increase in numbers. Bloodcorpuscles penetrate the degenerated portions of the myelin cords, but disappear again. The differentiated nerve cells do not multiply by division, but by means of neuroblasts, which originate in the central mass of nerve fibers as well as in the layer of ganglia. Probably both neuroglia tissue and ganglia contribute to the formation of the neuroblasts. The myelin cords do not pass through a blastema stage. They grow as a well differentiated tissue, and are easily discerned in the regenerated piece. Together with the epithelium and the bloodvessels, they are the first tissues which can be distinguished, all the remaining tissues still being in a blastematous stage.

4. The connective tissue. The first elements which later on go to construct the new connective tissue are probably evolved from the primary blastema, a product of the agglutinated bloodcorpuscles.

The general results of this study may easily be expressed in the following two sentences:

1. All new tissues with the exception of the dermal connective tissue are produced by the preexisting tissues of the same kind.

2. Sepia occasionally replaces a lost arm by means of compensatory regulation (development of the correlated buccal arm to replace a lost one). 


\section{APPENDIX}

In the introduction mention was made of the extirpation of the lens. As, however, not many animals survived this operation for any length of time, there was not enough material at my disposal to enable me to give any kind of detailed account of the regeneration of this organ. After extirpation of the lens the injured eye lost its ability to perceive light. A few animals, however, survived the operation and lived for over. ten weeks after it had been performed. On these animals I noticed that the injured eye had regained its sensitiveness to light after a period of about eight weeks. This fact was ascertained in the following manner. It is well known that the circular pad of skin which surrounds the visible parts of the eye acts as a lid. If the eye is suddenly exposed to light, this pseudolid shuts. If I exposed an eye to the light whose lens had been extirpated a few days previously, then the pseudolid did not close. Ten weeks after operation, however, the same eye showed the characteristic contraction of the pseudolid when suddenly exposed to light. Some animals even survive the loss of a whole eye. While at Naples I one day received a sepiola (from Doctor Naef), which had completely lost its one eye. The wound was healed, but I could not detect any signs of regeneration. Perhaps the animal had been injured just a few days before its capture. 


\section{LITERATURE CITED}

Aufrecht, E. 1890 Ueber die Genese des Bindegewebes nebst einigen Bemerkungen über die Neubildung quergestreifter Muskelfasern und die Heilung per primam intensionem. Virchows Arch., Bd. 44.

Baitsell, G. A. 1916 The origin and structure of a fibrous tissue formed in wound healing. Anat. Rec., vol. 10.

v. BaLlowitz, E. 1893 Ueber den feineren Bau der Muskelsubstanz, Erstens die Muskelfaser der Cephalopoden. Ärch. f. mikr. Anat., Bd. 39, S. 592-309.

Bardeen, Ch. R. 1904 American Journal of Physiology, vol. 5.

Barfurth, D. 1891 Zur Regeneration der Gewebe. Arch. f. mikr. Anat., Bd. 37 , S. $406-492$.

Regeneration u. Involution. Merkel u. Bonnet, Ergebnisse der Anatomie.

BAUer, V. 1909 Einführung in die Physiologie der Cephalopoden. Mitt. d. zoolog. Stat. zu Neapel, Bd. 19, S. 149-268.

van Beneden, P. J. 1898 Mémoire sur l'Argonaute (nouveaux mém. de l'Acad. Roy. de sc. de Bruxelles, 1898.

Billroter, Th. Zitiert nach Marchand.

Boвretzky, N. 1877 Untersuchungen über die Entw. der Cephalopoden Nachr. v. d. k. Gesell. d. Kunde d. Natur. Antrop. u. Ethnogr. Moskau. Bd. 24.

Bordage, ED. 1914 Phénomènes histolytiques observés pendant la régénéra. tion des appendices chez certains Orthoptères. C. R. Acad. de Sc. Paris, T. 161, p. 125.

Brock, J. 1886 Indische Cephalopoden. Zoolog. Jahrb., Bd. 2, S. 591-593.

Brown-Sequard 1850 Régénération des Tissus de la moelle épinière. Gaz. méd., 1850 , p. 250.

BRYNES, E. F. 1899 On the regeneration of limbs in frogs after the extirpation of limb rudiments. Anat. Anz., Bd. 15.

Capraso, E. Sulla rigenerazione de midollo spinale della coda dei Tritoni. Ziegler's Beiträge, Bd. 5.

Catannt, Fru. S. 1885 Sulla Fisiologia del gran Simpatico. Gazz. degli Osp.

ChEron, J. 1866 Recherches pour servir à l'histoire du système nerveux des Cephalopodes dibranchieux. Ann. Sc., T. 5. (5ème série), p. 1-122.

Chun, C. Ueber die Natur und die Entwicklung der Chromatophoren bei den Cephalopoden. Verh. d. deutsch.-zoolog. Ges., 12. Vers. S. 162-182.

Coen, P. E. 1888 Ueber die Heilung von Stichwunden des Gehirns. Ziegler's Beiträge, Bd. 2.

Colosantr, J. 1876 Anatomische und physiologische Untersuchungen über die Arme der Cephalopoden. Reichert u. Dubois-Reymond's Arch. f. Anat.

- Conmeim 1869 Ueber das Verhalten der fixen Bindegewebskörperchen bei Entzündungen. Virehows Areh., Bd. 45, S. 333.

Cucagna, G., und Nusbadm, J. 1915 Regeneration bei Nudibranchien. Arch. f. Ent. Mech., Bd. 41, S. ${ }^{558-579 .}$ 
Cú́not, L. 1891 Etude sur le sang et les glandes lymphatiques. Arch. de zool. expérim., T. 9, 2ème série, p. 13-90 et p. 593-670.

Cuvier, J. 1817 Mémoire pour servir à l'Histoire et à l'anatomie des Mollusques, p. 1-54 (Paris-Déterville).

Dentan, P. 1873 Quelques recherches sur Ia Régénération fonctionnelle et anatomique de la moelle épinière. Berne.

Dominici, M. 1911 Experimenteller Beitrag zum Studium der Regeneration der peripheren Nerven. Berliner klin. Wochenschrift, Jahrb. 48.

Ebrrsbach, A. 1915 Zur Anatomie von Cirroteuthis Umbellata Fischer und Stauroteuthis sp. Zeitschr. f. wiss. Zool., Bd. 93, Heft 3.

Eıснновsт, H. 1875 Ueber die Éntwicklung des menschl. Rückermarkes u. seiner Formelemente, Virchows Archiv., Bd. 64, S. 425.

EIsIG, H. Biologische Studien. Kosmos 12.

FAussex, V. Ueber die sogenannten 'Weissen Körper,' sowie über die embryonale Entwicklung desselben, der Cerebral ganglien u. des Knorpels bei Cephalopoden. Acad. Imp. Sc. St. Petersburg. 7ème Série, T. 41, n. 9.

Fernandez, Mig. 1907 Zur Histologie des Tentacles von Nautilus pompilius. Zeitschr. f. wiss. Zool., Bd. 88.

Flexner, S. 1898 The regeneration of the nervous system of Planaria torva (maculata), and the anatomy of the double-headed forms. Jour. Morph., vol. 14.

Fraisse, P. 1886 Die Regeneration von Geweben und Organen bei den Wirbeltieren. Biolog. Zentralbl.

Fredirica, L. Recherches sur la physiologie du poulpe commun. Arch. de zool. expér., T. 7.

FriedLënder, B. 1895 Ueber die Regeneration herausgeschnittener Teile des Zentralnervensystems von Regenwürmern. Zeitschr. f. wiss. Zool., Bd. 60 .

Friedmann 1888 Ueber progressive Veränderungen der Ganglienzelle bei Entzündungen u. Nervenktankheiten. Arch. f. Psych., Bd. 13, S. 244.

Friedrich, P. 1906 Regeneration der Beine und Autotomie bei Spinnen. Arch. f. Ent.-Mech., Bd. 20.

FrItsch, C. 1910 Regenerationsvorgänge des Gliedmassenskelettes der Amphibien. Zoolog. Jahrb. Abt. f. allg. Zool., Bd. 30, Heft 3.

Gariaeff, Wr. 1901 Histologie des Nervensystems der Cephalopoden. Zeitsehr. f. wiss. Zool., Bd. 92, S. 149-186.

GEDDES, P. On coalescence of amoeboid cells into plasmodia and on the so-called coagulation of intervertebrate fluids. Proc. of Royal Soc. London, vol. 30 .

Grenacher, H. 1874 Zur Entwicklungsgeschichte der Cephalopoden. Zeitschr. f. wiss. Zool., Bd. 24, S. 419-498.

Grumpe, G. 1913 Das Blutgefässystem der Dibranchiaten Cephalopoden. Teil I, Octopoda. Zeitschr. f. wiss. Zool., Bd. 104, Heft 4, S. 531-631.

Gú́rin, J. 1908 Contribution à l'Étude des systèmes cutané, musculaire et nerveux de l'appareil tentaculaire des Cephalopodes. Arch. de Zool. experim. T. 8, 4ème série, p. 1-178. 
Hanko, B. 1913 Ueber das Regenerationsvermögen und die Regeneration verschiedener Organe von Nassa mutabilis (L.), Arch. f. Ent-Mech., Bd. 38, Heft 3.

1913 Ueber einen gespaltenen Arm von Octopus vulgaris. Ibid., Bd. 37, S. 217-222.

Hanns, Dr. 1892 Ueber Degenerations- u. Regenerationsvorgänge im Rückenmark des Hundes nach Durchschneidung. Ziegler's Beiträge, Bd. 12, S. 33 .

Hescheler, K. 1897 Ueber Regenerationsvorgänge bei Lumbriciden. Jenache Zeitschrift, Bd. 30 .

1898 Ueber Regenerationsvorgänge bei Lumbriciden. II. Teil. Jena, Gustav Fiseher.

Hilitg, R. 1912 Das Nervensystem von Sepia officinalis L. Zeitschr. f. wiss. Zool., Bd. 101, S. 736-806.

Jakubski, A. W. 1915 Studien über das Gliagewebe der Molusken. II. Teil, Cephalopoden. Zeitschr. f. wiss. Zool., Bd. 112, S. 48-68.

Keresztzsegy, J. 1892 Ueber Degenerations- u. Regenerationsvorgänge im Rückenmark des Hundes nach Durchschneidung. Ziegler's Beiträge, Bd. 12 .

KLınz, J. 1914 Experimentelle Schwanzregeneration bei Bilchen, Myoxidae. Arch. f. Ent.-Mech., Bd. 40, S. 344-368.

KöLliken, A. 1844 Entwickl. Geschichte der Cephalopoden. Meyer u. Zeller, Zürich.

Kollmann, M. 1908 Recherches sur les Leucocytes. Ann. Sc. nat., 9ème sćrie, T. 8.

Konschelt, E. 1907 Regeneration und Transplantation. Jena. Festschrift für Leuckart. Entwicklungsgeschichte der Cephalopoden.

LAxG, P. 1909 Ueber Regeneration bei Planarien. Arch. f. mikr. Anat., Bd. 79 , S. $361-424$.

1910 Experimentelle und histologische Studien an Tubellarien. Ibid., Bd. 82 .

Loeb, Leo 1908 Vergleichende Untersuchingen über die Thrombose. Virchows Arch., Bd. 185, S. 160.

1909 Blutgerinnung bei Wirbellosen. Biochem. Zeitschr., Bd. 24, S. 478-495.

Marivescu 1894 Sur la régénération des centres nerveux. Compte rendu de la soc. de Biolog., 17 Mai.

Marchand, J. 1901 Prozesse der Wundverheilung. Deutsche Chirurgie, Bd. 16.

Masius v. vay Lair 1870 Bullet. de l'Acad. roy. de Belgique, T. 21.

Metschnikoff, E. 1892 La phagocytose musculaire. Ann. de l'Institut Pasteur, T. 6, p. 1-12.

Modrao, C. 1885 Giornale della R. Acad. di Torino, Gennaio-Febr.

Moreno, J. 1907 La candès ganglienas en los tentaculos de Cephalopodi. Rev. real. Acad. de Cienzas exactas bisy, nat. de Madrid, T. 5.

Morgan-Moskowski 1907 Regeneration. Leipzig.

Mühlmand, M. 1811 Studien über den Bau und das Wachstun der Nervenzelle. Arch. f. mikr. Anat., Bd. 77. 
Mühlmañ, M. 1912 Mikrochemische Untersuchungen an der wachsenden Nervenzelle. Ibid., Bd. 79.

MÜlLER, J. 1864-1865 Regeneration der Wirbelsäule und des Rückenmarks bei Tritonen und Eidechsen. Abhandl. d. Senkenberg. nat. Ges., Bd. 5.

NaEF, A. Cephalopoda. Handwörterb. d. Naturwiss., Bd. 2. Teutologische Notizen. Zoolog. Anz., Bd. 40.

NAUnyn, Bernh. 1874 Ueber Regeneration u. Veränderungen im Rückenmark nach streckenweiser totaler Zerstörung derselben. Arch. f. exper. Pathol. u. Pharmat, Bd. 2.

Nusbadm, J. Vergleichende Regenerationsstudien. Zeitschr. f. wiss. Zool., Bd. 79.

Ost, J. 1906 Zur Kenntnis der Regeneration der Extremitäten bei den Arthropoden. Areh. f. Ent.-Mech., Bd. 22, S. 289-325.

Owsjannikow, P. Ueber das central Nervensystem und das Gehörorgan der Cephalopoden. Mem. Ac. St. Petersb.

Pfefferkorn, A. 1915 Das Nervensystem der Octopoden. Zeitschr. f. wiss. Zool., Bd. 114, Heft 3.

REED, M. A. 1905 The regeneration of the first leg of the crayfish. Arch. $f$. Ent. Mech., Bd. 18.

Reichensperger, A. 1912 Beiträge zur Histologie und zum Verlauf der Regeneration bei Crinoiden. Zeitschr. f. wiss. Zool., Bd. 101, S. 1-69.

Rievel, H. 1896 Die Regeneration des Vorderdarmes und Enddarmes bei einigen Aneliden. Zeitschr. f. wiss. Zoolog., Bd. 62, S. 289-341.

RIgGenBaCH, E. 1901 Beobachtungen über Selbstverstümmelung. Zool. Anzeiger, Bd. 24, S. 587-593.

1902 Die Selbstverstümmelung der Tiere. Anat. Hefte, II. Abt.

RindFLEISCH, ED, Zitiert nach Marchand.

Sanarelli 1896 I processi riparativi nel cervello e nel cervelletto. R. acad. dei Lincei.

Schultz, E. Ueber die Regeneration der Spinnenfüsse. Trudy Petersburg. Obes. Estesvoip., Bd. 29.

Stevens, N. M. 1909 A histological study of regeneration in Planaria simplissima, P. maculata, and Pl. morgani. Arch. f. Ent.-Mech., Bd. 24. 1907 Notes on regeneration in Planaria lugubris. Ibid., Bd. 13.

Strozbe, H. 1894 Experimentelle Untersuchungen über die degenerativen und reparativen Vorgänge bei der Heilung von Verletzungen des Rückenmarks, nebst Bemerkungen zur Histogenese der sekundären Degeneration in Rückermark. Zieglers Beiträge, Bd. 15.

Tecrow, G. 1910 Zur Regeneration des Weichkörpers bei den Gatropoden. Arch. f. Ent.-Mech., Bd. 31.

Tedeschi, A. 1897 Anatomisch-experimenteller Beitrag zum Studium der Regeneration des Gewebes des Zentralnervensystems. Beitr. z. Anat. u. path., Bd. 21, S. 43-72.

Thulin, J. Beitrag zur Frage der Muskeldegeneration. Arch. f. mikr. Anat., Bd. 79, S. 208-230.

UEXKÜLL, F. von 1893 Physiologische Untersuchungen an Eledone moschata. II. Die Reflexe der Arme. Zeitsčhr. f. Biolog., Bd. 30. 
Ussow, M. 1894 Zoologisch-embryologische Untersuchungen. Die Kopffüsler. Arch. f. Nat. Gesch., Bd. 40, S. 329.

1881 Die Entwicklung der Cephalopoden. Arch. de Biol., T. 2, F. 4.

Verill, A. 1892 Cephalopodes of N. E. America. Transact. of Connecticut Acad., vol. 5, p. 260.

Vilalleton, L. 1888 Recherches sur les premières phases du développement de la seiche 1888. Ann. de Sc. nat., 7ème série zool., T. 6.

Walter 1853 De regeneratione ganglionum. Diss. inaug. Bonnae.

WEIGL, R. 1910 Ueber den Golgi-Kopschen Apparat in der Ganglienzelle der Cephalopoden. Anzeig. d. akad. d. Wiss. zu Krakau.

ZIEGLER, E. 1895 Lehrbuch der path. Anatomie, Bd. 2, S. 354. 
PLATES 


\section{PLATE 1}

\section{DESCRIPTION OF FIGURES}

1 Transverse section of an arm of Octopus vulgaris according to Guérin. $a$, epithelium; $b$, subcutaneous connective tissue; $c$, chromatophores; $d$, vein; $e$, dermal musculature; $f$, perimuscular connective-tissue membrane; $g$, external oblique muscle; $i$, inner oblique muscle; $j$, inner lateral longitudinal muscle; $k$, external longitudinal muscle; $l$, internal longitudinal muscle bundle; $m$, transverse musculature; $n$, perinervous connective tissue; $o$, layer of ganglia; $p$, central mass of nerve fibers (neuropil); $q$, myelin cords; $r$, brachial arteries; $s$, nerve; $t$, sucker; $u$, sucking cavity; $v$, adhesive part; $w$, sphincter.

2 Muscles according to Ballowitz. $A$, longitudinal section; $B$, transverse section; $a$, spiral fibers; $b$, core; $c$, nucleus.

3 Large nerve cell in the axial nerve of the arm of Octopus vulgaris. $a$, glia fiber; $b$, glia nucleus; $c$, ectoplasm; $d$, endoplasm; $e$, Nissl granules; $k$, nucleus; $k^{\prime}$, nucleolus.

4 Blood-corpuscles from the brachial arteries. 


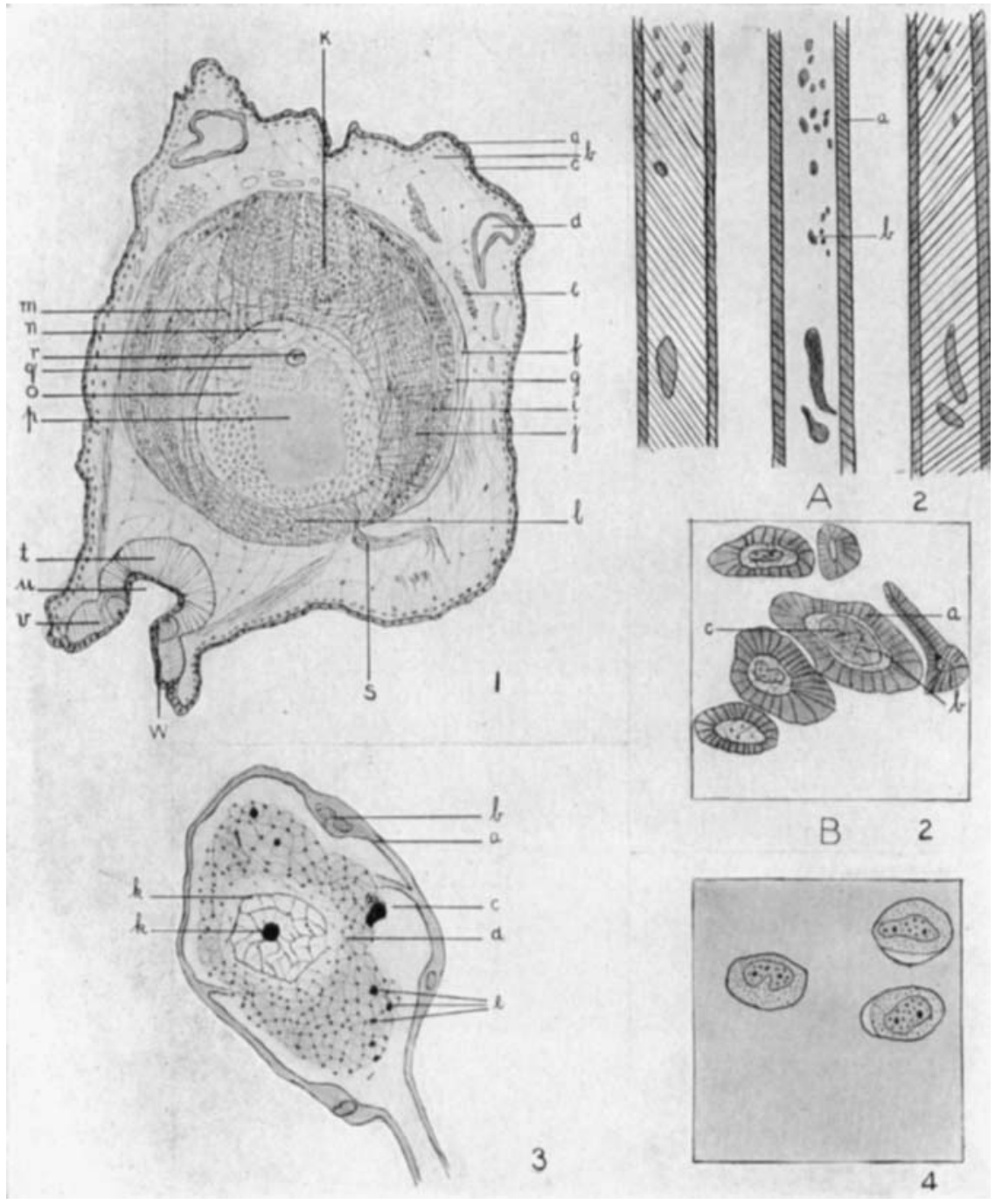




\section{PLA'TE 2}

\section{DESCRIPTION OF FIGURES}

5 Wound of an Octopus vulgaris arm one and a half hours after operation. $a$, axial nerve; $b$, myelin cords.

6 Wound of Oetopus vulgaris arm ten hours after operation.

7 Healed wound of an Octopus vulgaris arm one day after operation. Distal suckers are drawn up.

8 Little knob first visible sign of regeneration three days after operation. 


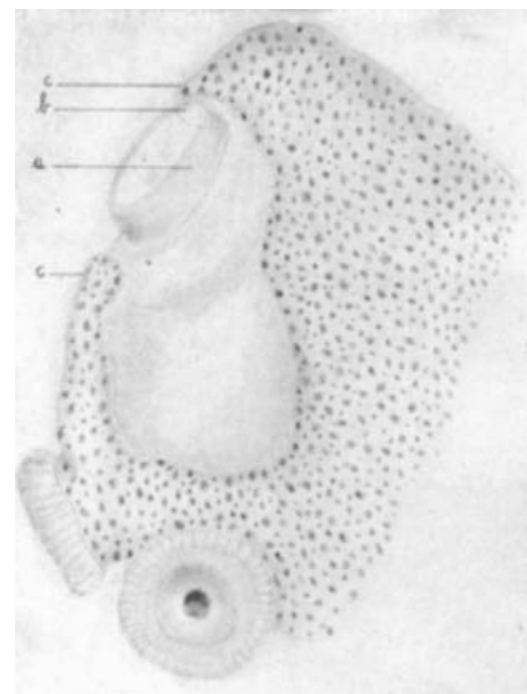

5

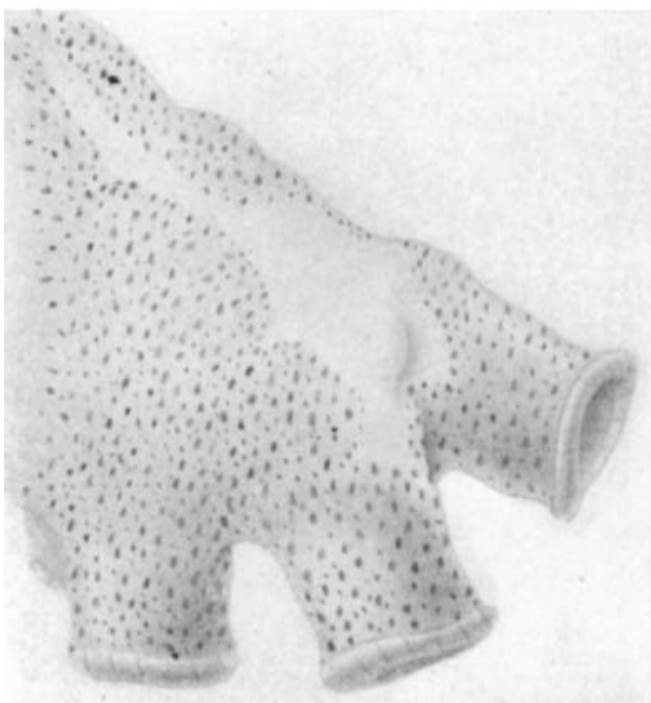

7

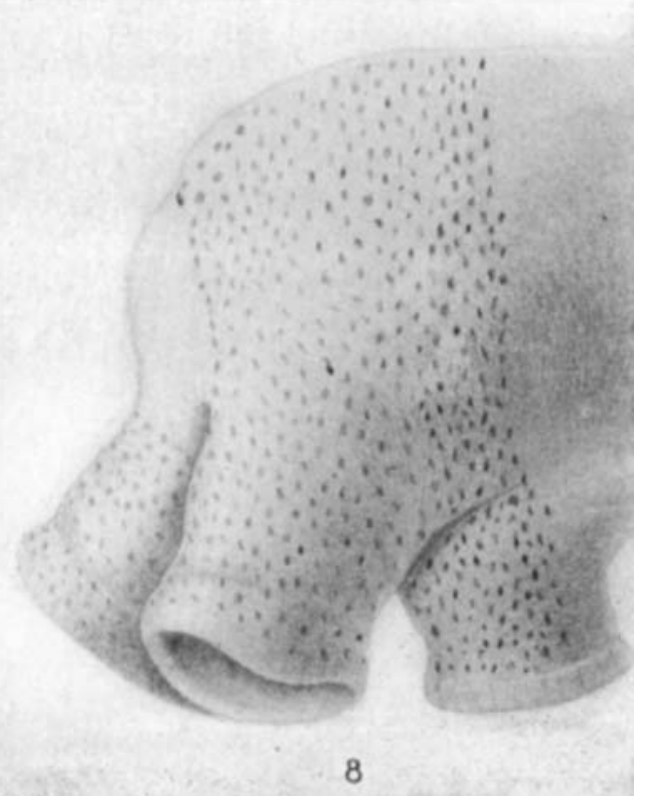




\section{PLATE 3}

DESCRIPTION OF FIGURES

9 Dome-shaped knob three days after operation.

10 Regenerated piece eleven days after operation. Little transverse folds are suckers at a very early stage of development.

11 and 12 Regenerated piece three weeks after operation. 


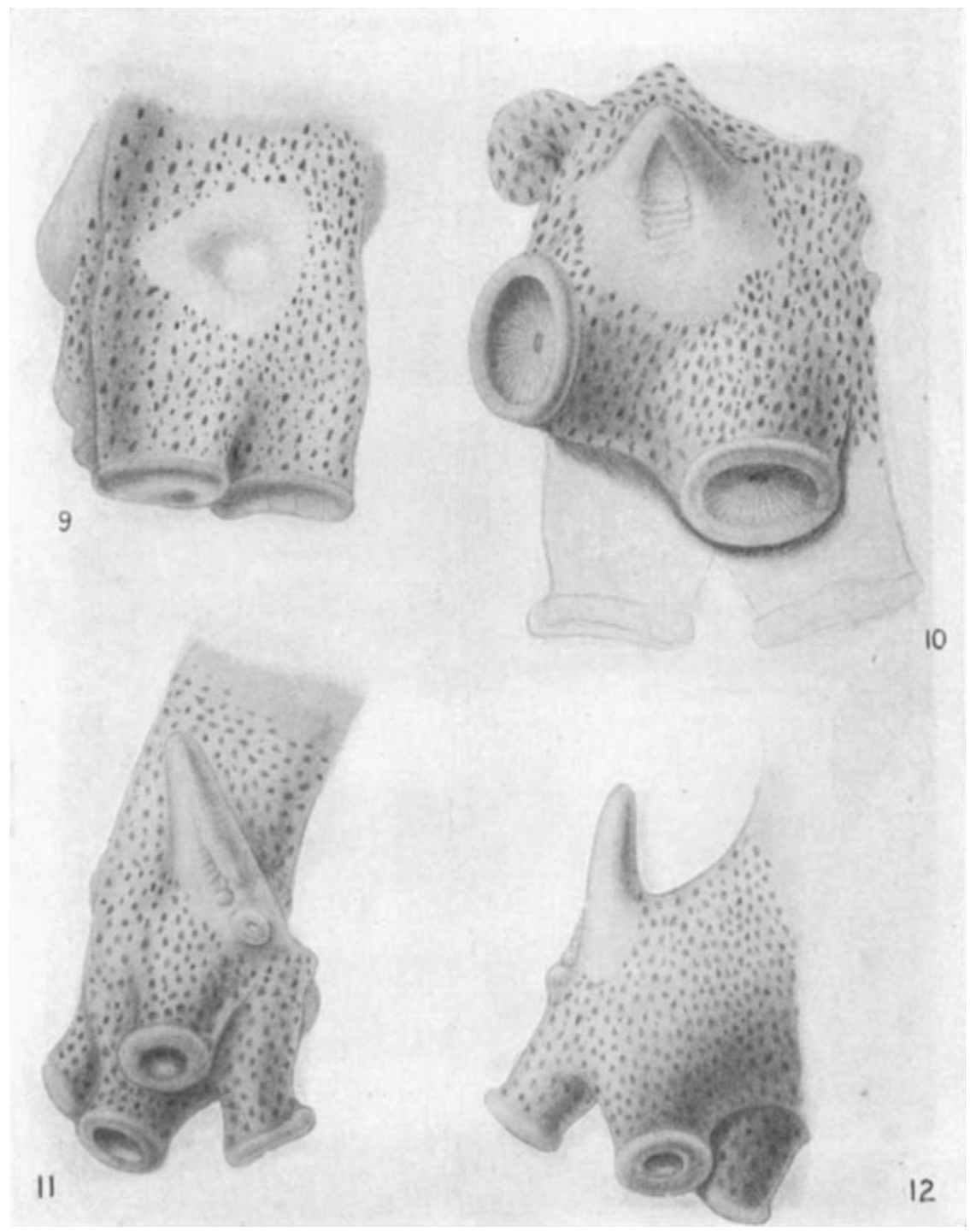


PLATE 4

\section{DESCRIPTION OF FIGURES}

13 and 14 Regenerated piece three weeks after operation.

15 Regenerated piece of an Octopus vulgaris arm four weeks after operation.

16 Regenerated piece of an Octopus vulgaris arm six weeks after operation. 


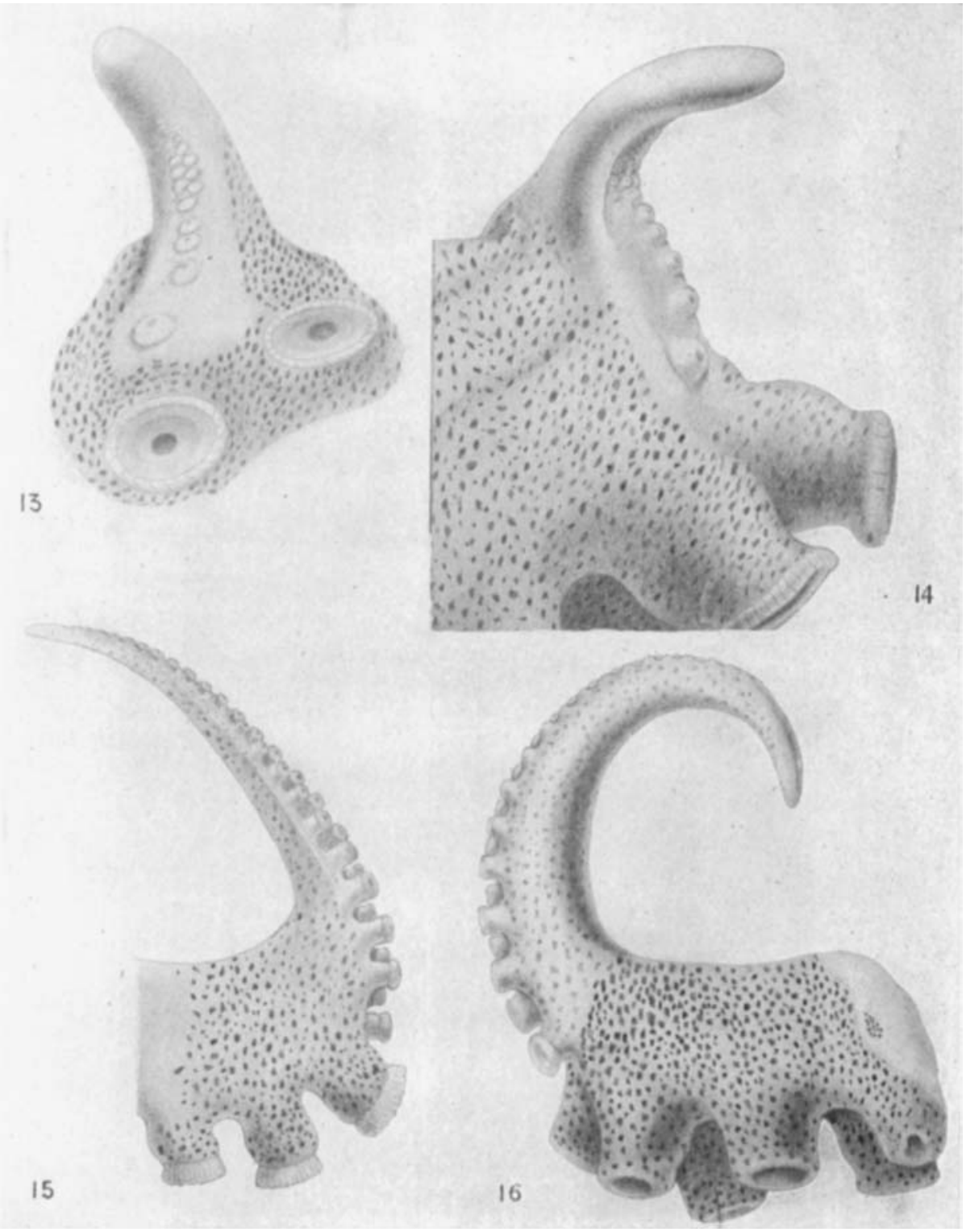




\section{PLATE 5}

\section{DESCRIPTION OF FIGURES}

17 Longitudinal section through the wound shown in figure 5 (one-half hour after operation). $a$, epithel; $b$, subeutaneous connective tissue; $c$, chromatophores; $d$, musculature; $e$, artery; $f$, myelin cord; $h$, neuropil; $i$, layer of nerve cells; $j$, sucker.

18 Open brachial artery six hours after operation.

19 Agglutinating blood-corpuseles.

20 Brachial artery closed by a clot of agglutinating blood-corpuseles.

21 Primary blastema evolved from blood-corpuseles.

22 Longitudinal section through an Octopus vulgaris arm ten hours after operation. Preliminary covering of the wound formed by agglutinating bloodcorpuscles. 


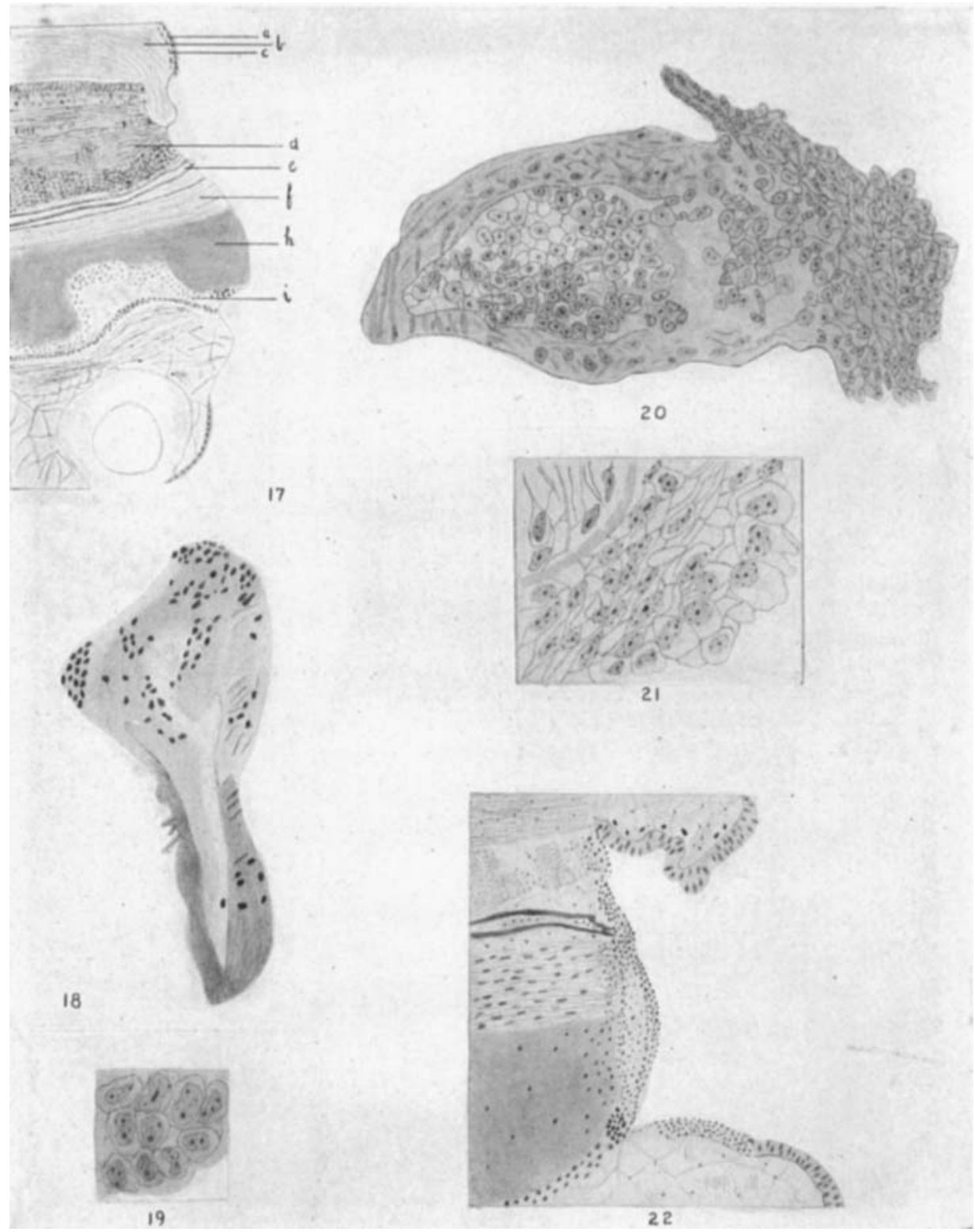




\section{PLATE 6}

\section{DESCRIPTION OF FIGURES}

23 Healed wound near the tip of the arm. a, very thin layer of primary blastema.

24 Octopus vulgaris arm forty-six hours after operation. Newly formed epithelium.

25 Octopus vulgaris arm 1 to 2 days after operation. Wound completely healed, newly formed epithelium with subjacent primary blastems.

26a Newly formed syncytial epithelium one day after operation.

26b Amitotic division of epithelial nuclei. 


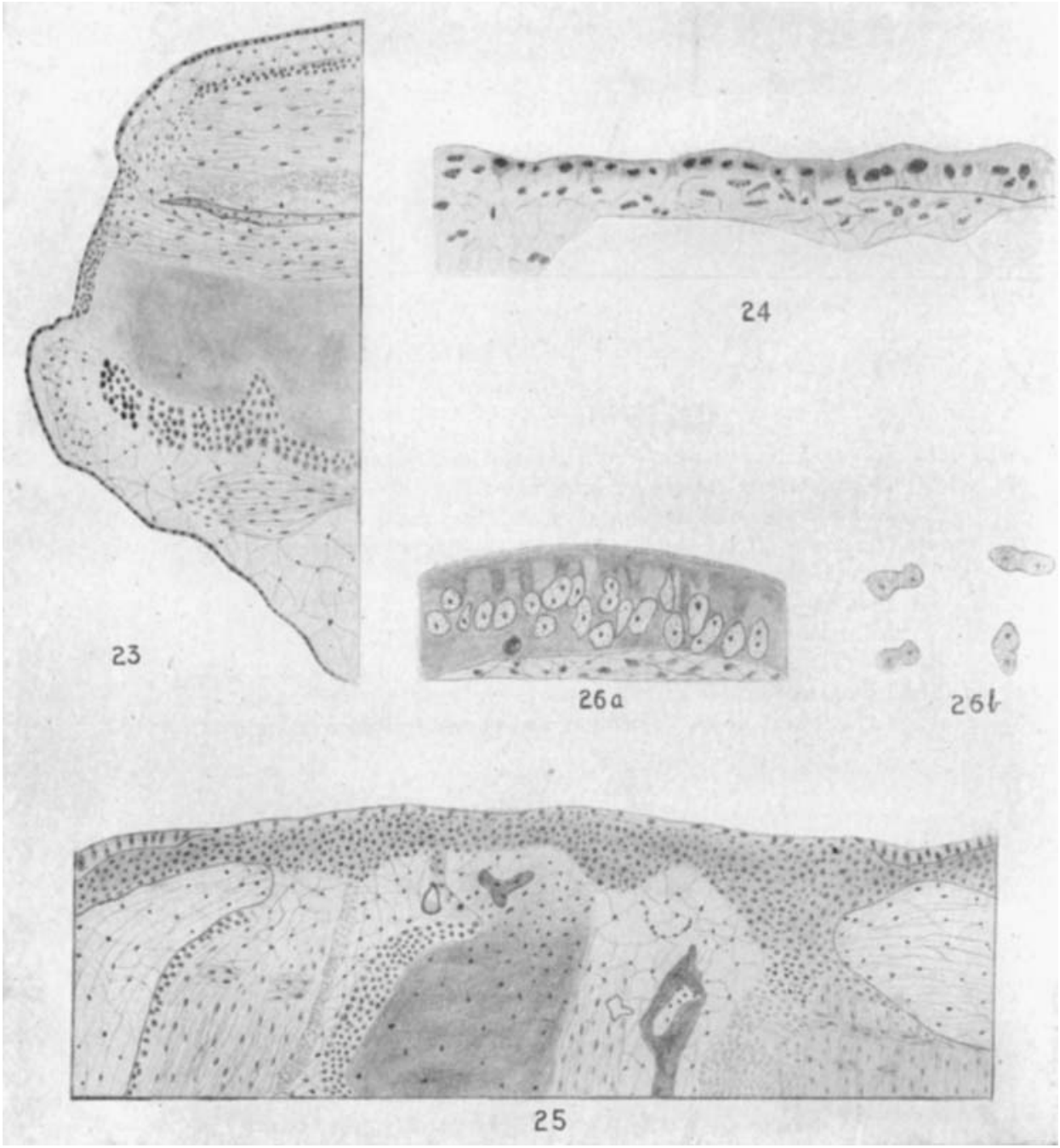




\section{PLATE 7}

\section{DESCRIPTION OF FIGURES}

27 Degenerating muscle fibers one and a half hours after operation.

28 Degenerating muscle nuclei.

29 Blood-corpuscles among degenerating muscle fibers and nuclear fragments ten hours after operation.

30 Sarcoblasts two days after operation.

31 Primary and second blastema.

32 Mitosis of sarcoblasts.

33 Formation of the sucker muscles eleven days after operation.

34 Invagination of a sucker three weeks after operation. Section made through the lowest newly formed sucker shown in figures 13 and 14. 
MATHIIDE M. LANGE

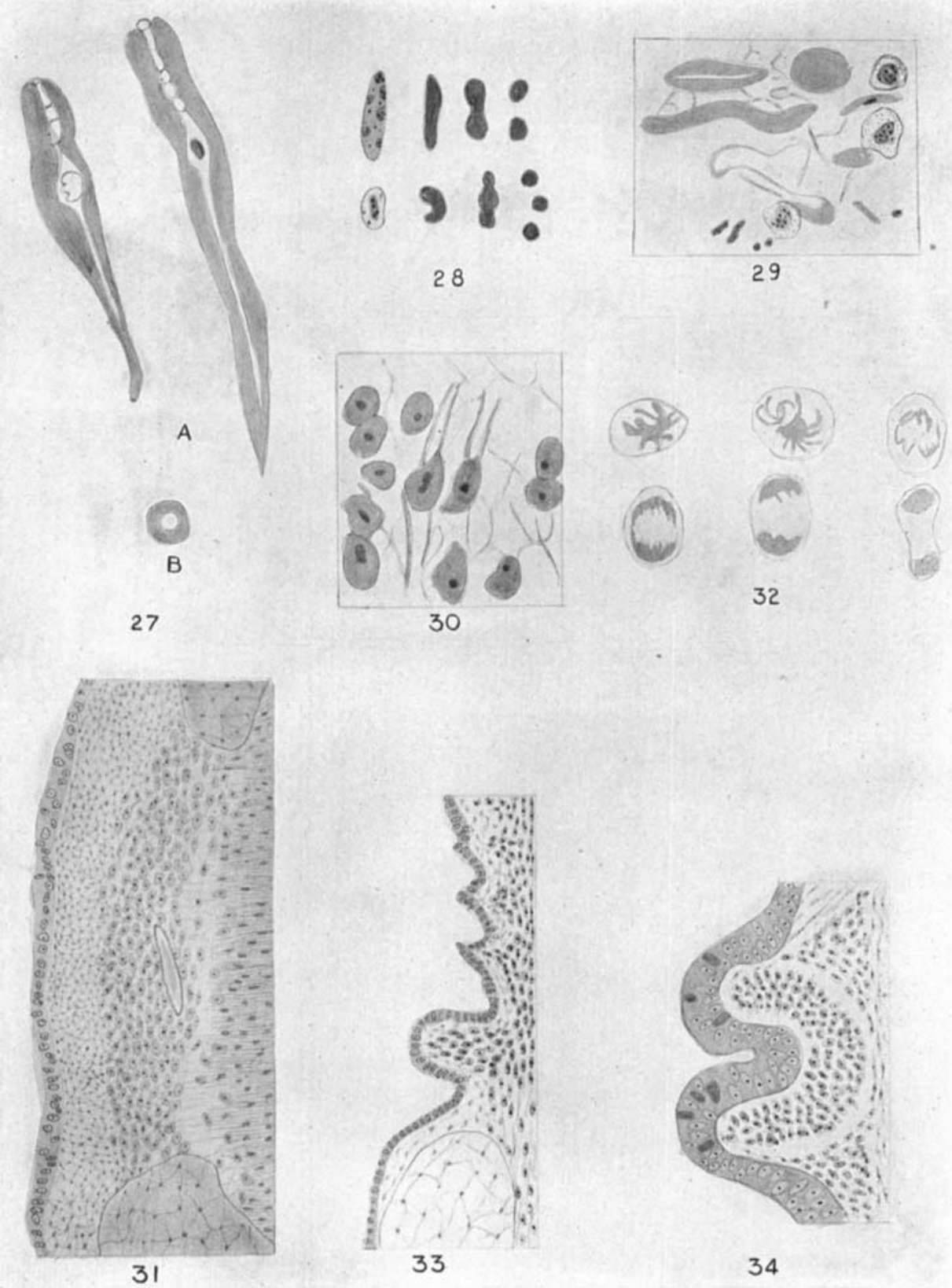




\section{PLATE \&}

\section{DESCRIPTION OF FIGURES}

35. Degenerating nerve nuclci one and a half hours after operation.

36 Inflated myelin fibers six hours after operation.

37 Increase of nuclei in the neuropil.

38 Tip of a regenerated piece three weeks after operation. Section made through piece shown in figures 13 and 14 .

39 Nerve growing into the primary blastema. a, young nerve cell. 


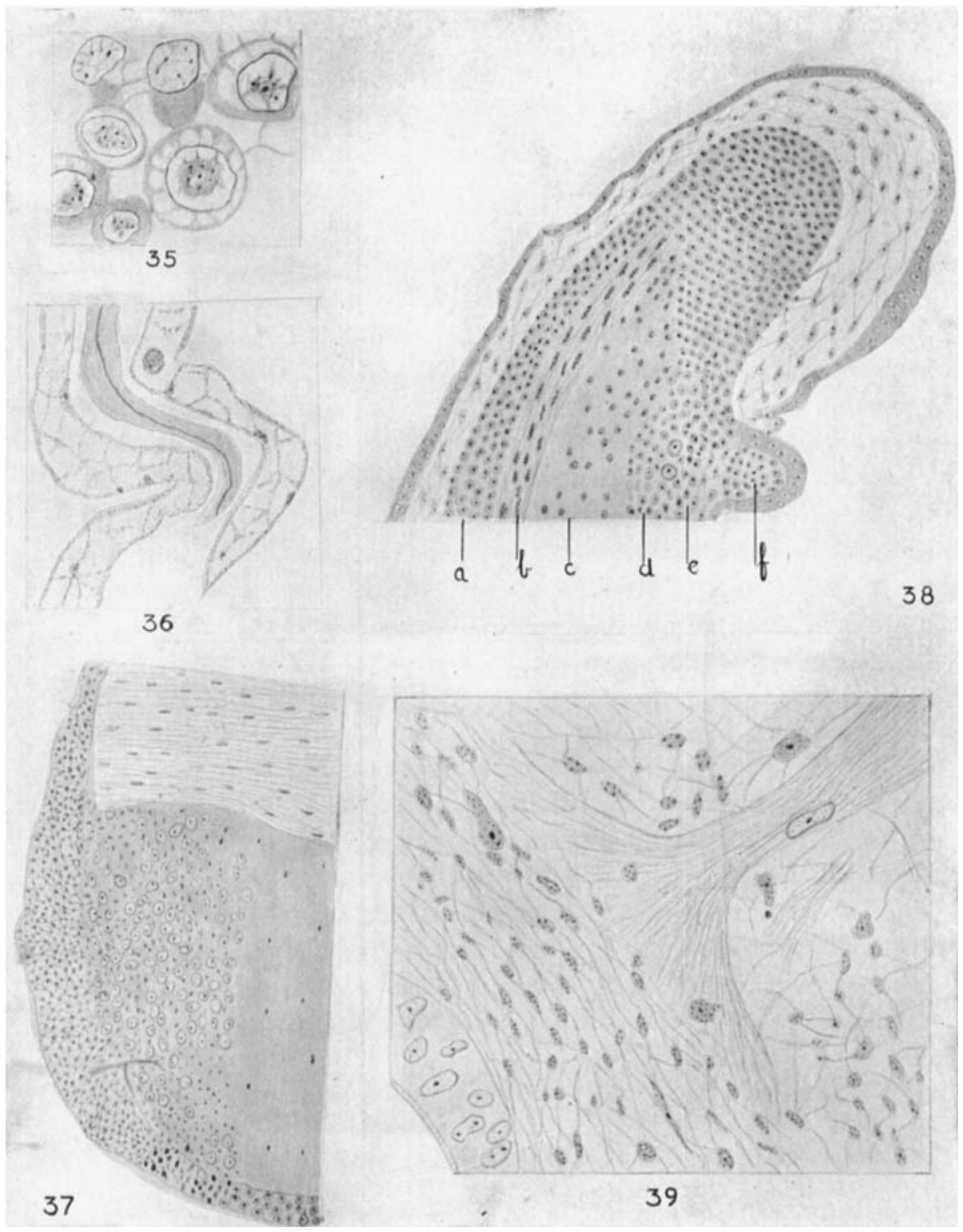

